(C) This manuscript version is made available under the CC-BY-NC-ND 4.0 license https://

creativecommons.org/licenses/by-nc-nd/4.0/

\title{
THE CARRANCAS FORMATION, BAMBUÍ GROUP: A RECORD OF PRE-MARINOAN SEDIMENTATION ON THE SOUTHERN SAO FRACISCO CRATON, BRAZIL
}

Gabriel J. Uhlein ${ }^{1,3 *}$; Alexandre Uhlein ${ }^{1}$; Galen P. Halverson ${ }^{2}$ Ross Stevenson ${ }^{3} ;$ Fabrício A. Caxito $^{1}$; Grant M. Cox ${ }^{2}$; Jorge F.M.G. Carvalho ${ }^{4}$

1 - Centro de Pesquisas Manoel Teixeira da Costa, Instituto de Geociências, Universidade Federal de Minas Gerais, Campus Pampulha, Av. Antônio Carlos 6627, 31270-901, Belo Horizonte, MG, Brazil - *corresponding author: guhlein@gmail.com;

2 - Department of Earth and Planetary Sciences/GEOTOP, McGill University, Montréal, Québec H3A 0E8, Canada 3 - GEOTOP, Université du Québec à Montréal, P.O. Box 8888, Station Centre Ville, Montreal, Quebec H3C 3P8, Canada 4 - Petrobras S.A., Av. Nossa Senhora da Penha, 1688, 29057-570, Vitória, ES, Brazil.

\section{ABSTRACT}

The Carrancas Formation outcrops in east-central Brazil on the southern margin of São Fracisco craton where it comprises the base of the late Neoproterozoic Bambuí Group. It is overlain by the basal Ediacaran cap carbonate Sete Lagoas Formation and was for a long time considered to be glacially influenced and correlative with the glaciogenic Jequitaí Formation. New stratigraphic, isotopic and geochronologic data imply that the Carrancas Formation was instead formed by the shedding of debris from basement highs uplifted during an episode of minor continental rifting. Reddish dolostones in the upper Carrancas Formation have $\delta^{13} \mathrm{C}$ values ranging from +7.1 to $+9.6 \%$, which is a unique $\mathrm{C}$ isotopic composition for the lowermost Bambuí Group but similar to values found in the Tijucuçu sequence, a pre-glacial unit in the Araçuaí fold belt on the eastern margin of the São Francisco craton. The stratigraphic position below basal Ediacaran cap carbonates and the highly positive $\delta^{13} \mathrm{C}$ values together imply a Cryogenian interglacial age for the Carrancas Formation, with the high $\delta^{13} \mathrm{C}$ values representing the so-Keele peak, which precedes the preMarinoan Trezona negative $\delta^{13} \mathrm{C}$ excursion in other well characterized Cryogenian sequences. Hence, The Carrancas Formation pre-dates de Marinoan Jequitaí Formation and represents an interval of Cryogenian stratigraphy not previously known to occur on the São Francicso craton. Documentation of Cryogenian interglacial strata on the São Francisco craton reinforces recent revisions to the age of Bambuí Group strata and has implications for the development of the Bambuí basin. 
Keywords: Neoproterozoic; Marinoan glaciation; isotope stratigraphy; Keele peak; São Francisco craton; Bambui Group.

\section{INTRODUCTION}

The end-Cryogenian glaciation (i.e. ca. 635 Marinoan event) left a unique imprint in the geological record in the form of lithologically and geochemically distinctive carbonates that were deposited globally during the post-glacial transgression (e.g.: Halverson et al., 2004; Allen and Hoffman, 2005; Shields, 2005; Hoffman et al., 2007). The sedimentary processes operating during this transgression remain controversial (e.g. James et al., 2001; Lamb et al. 2012), in particular with regards to the transition from glacially-related siliciclastics to deposition of carbonates typically associated with a tropical climate (Allen and Hoffman, 2005; Eyles and Januszczak, 2004; Font et al., 2010; Hoffman et al., 2007; Hoffman, 2011; Kennedy and Christie-Blick, 2011). Paleomagnetic and other paleogeographic constraints suggest that this glaciation occurred on a planet with sparse or no high latitude continents (Evans, 2000; Trindade and Macouin, 2007; Hoffman and Li, 2009).

A better understanding of this pivotal transition in Earth's history can be gleaned from integrated sedimentological, geochemical, geochronological and isotopic studies of the many Neoproterozoic siliciclastic-carbonate successions that were deposited at this time as the supercontinent Rodinia broke up, Despite a growing body of data and renewed interest in the late Neoproterozoic Bambuí Group on the southern margin of the São Francisco craton (east-central Brazil_, considerable debate persists over the age and origin of the Bambuí basin (Fig. 1). While it had long been thought that the Jequitaí Formation and overlying lower Sete Lagoas Formation in the lower Bambuí Fm. represent the older Cryogenian (Sturtian) glaciation and its overlying cap carbonate sequence, respectively (e.g. Babinsky et al. 2007; Vieira et al, 2007b), more recently, other authors have advocated that they are late Cryogenian-Ediacaran in age, based on a combination of sedimentological and isotopic characteristics (Caxito et al., 2012; Alvarenga et al., 2014). However, this significant chronostratigraphic revision to the lower Bambuí Group is complicated by the recent discovery of the distinctly late Ediacaran fossils Cloudina (Warren et al., 2014) and ca. 550 Ma detrital zircons in the middle of the Sete Lagoas Formation (Paula-Santos et al., 2015).

Additional debate surrounds the nature of the Carrancas Formation, which locally comprises the lower Bambuí Group (Fig. 2). The Carrancas Formation outcrops in basement lows, below the cap carbonates of the Sete Lagoas Formation and was long considered to be glaciogenic and correlated with the Jequitaí Formation. However, no unambiguous glacial evidence has been found 
1 (e.g.: Martins-Neto et al., 2001), and Caxito et al. (2012) argued that some facies of the Carrancas

2 Formation are represent reworked post-Marinoan cap carbonate and basement.

Here we present stratigraphic analysis and new whole-rock geochemistry, $\mathrm{Nd}$ isotopes, $\mathrm{U}-\mathrm{Pb}$

4 geochronology and $\mathrm{C}$ and $\mathrm{O}$ isotopes on carbonate clasts and layers from three outcrop areas of the

5 Carrancas Formation that clarify its depositional environment and tectonic context. The data imply

6 that the Carrancas Formation pre-dates the end-Cryogenian glaciation and records sedimentation in

7 basement lows during an episode of minor continental extension on the southern São Francisco

8 paleocontinent. These interpretations have major implications for the Neoproterozoic stratigraphy of

9 the São Francisco craton and surrounding fold belts and motivate a new model of the sedimentary

10 processes and paleogeography before the end-Cryogenian glaciation in southwest Gondwana.

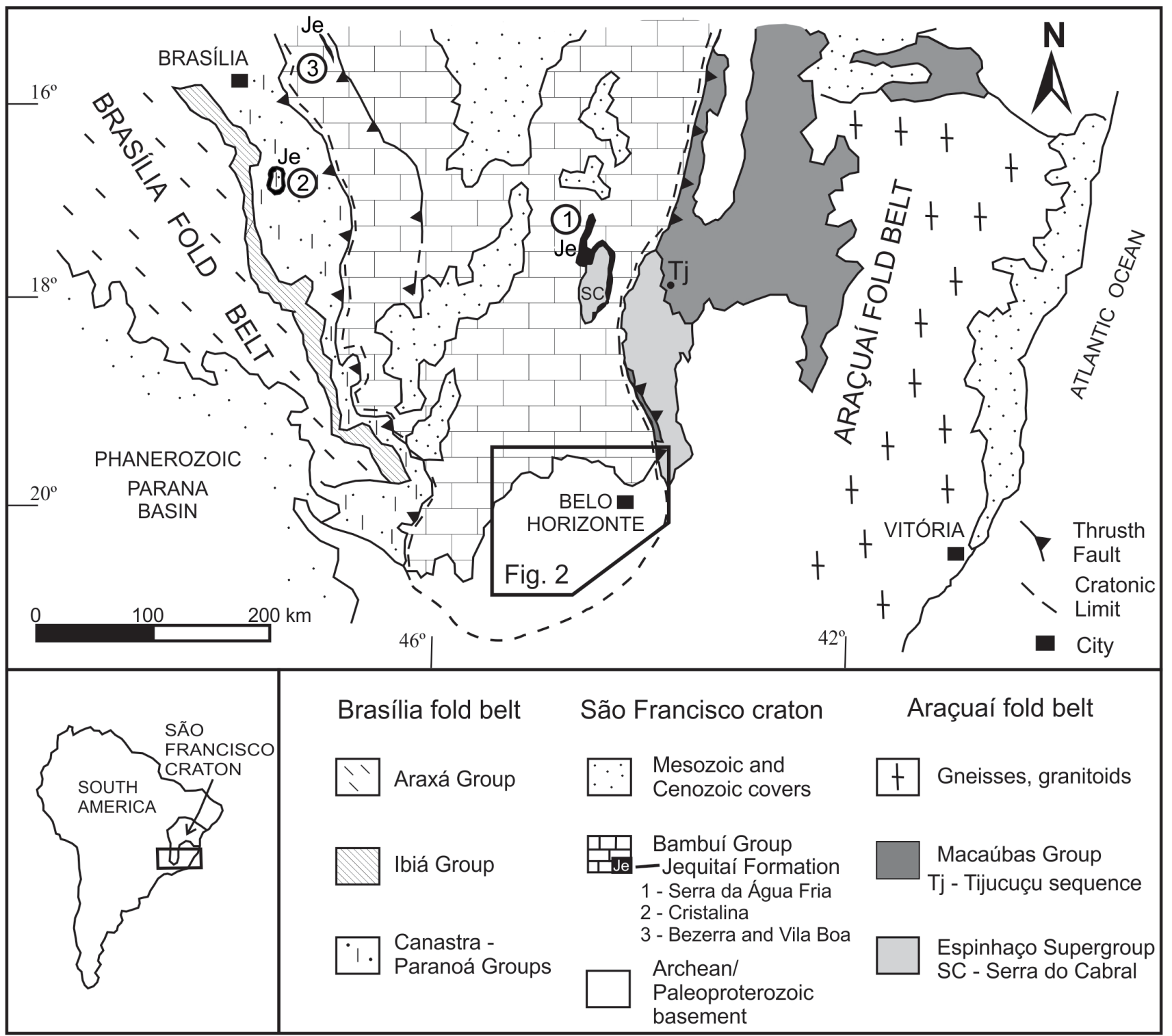


1 Fig. 1: Simplified geologic map of the central and southern São Francisco craton and marginal fold 2 belts. The circled numbers show locations where the Jequitaí Fm. occurs, and the location of the 3 Tijucuçu sequence is also shown. See Fig. 2 for detail of the region investigated for this project. 4 Geologic map after Almeida (1977), Alkmim and Marshak (1998) and Alkmim and Martins-Neto 5 (2001).

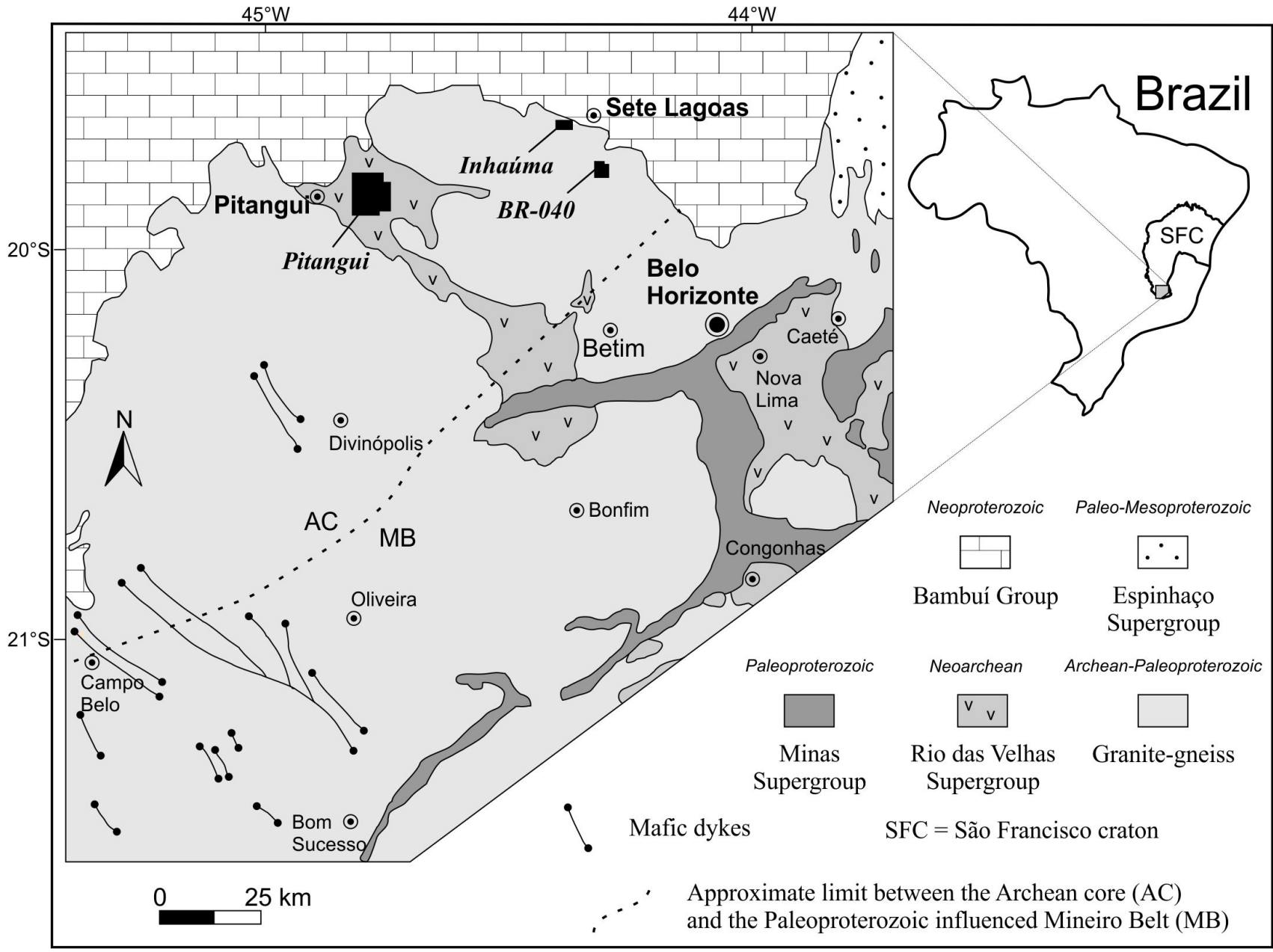

Fig. 2: Simplified geologic map of the southern São Francisco craton. Studied occurrence areas of the Carrancas Formation in black polygons; see text for stratigraphic details. Modified from Teixeira 9 et al. (2000).

\section{GEOLOGICAL SETTING}

\subsection{The Bambuí Group}

The Bambuí Group is a late $(<635 \mathrm{Ma})$ Neoproterozoic mixed carbonate-siliciclastic sequence that covers over $300,000 \mathrm{~km}^{2}$ of the São Francisco craton in east-central Brazil (Fig. 1; Alkmim and Martins-Neto, 2001; Sial et al., 2009). Dardenne (1978) defined six formations, from base to top: (1) Jequitaí / Carrancas Formation - conglomerates, sandstones and shales; (2) Sete Lagoas Formation - mainly carbonates; (3) Serra de Santa Helena Formation - siltstones, shales and rhythmites; (4) 
Lagoa do Jacaré Formation — oolitic and intraformational carbonates; (5) Serra da Saudade

2 Formation - siltstones, shales and sandstones; (6) Três Marias Formation - mainly sandstones.

3 Recently, a lateral equivalent to the Serra da Saudade Formation was proposed in the western part of

4 the basin: the Lagoa Formosa Formation, consisting of intraformational diamictite, siltstone, 5 sandstone, and lenses of limestone and jaspilite (Sial et al; 2009; Uhlein et al. 2011a). Although the 6 Bambuí Group is commonly considered to be conformable, Santos et al. (2004), Zalán and Romeiro7 Silva (2007) and Martins and Lemos (2007) interpreted a major unconformity in the middle of the 8 Sete Lagoas Formation separating a lower sequence deposited in an intracratonic basin from an upper foreland sequence. This interpretation was largely based on seismic and regional chemostratigraphic $\left(\delta^{13} \mathrm{C}\right)$ data; however, robust field evidence for the unconformity has not been documented yet.

The depositional age of the Bambuí Group is a topic of intense debate. Babinski et al. (2007) indicating that the Sete Lagoas Formation was a middle-Cryogenian (i.e. Sturtian) cap carbonate. However, the Sete Lagoas does not resemble typical post-Sturtian cap carbonates, and Caxito et al. (2012) instead argued for a basal Ediacaran age, supported by lithostratigraphic features (e.g. basal cap dolomite and overlying seafloor cements), carbon and oxygen isotope profiles, and ${ }^{87} \mathrm{Sr} /{ }^{86} \mathrm{Sr}$ signatures that allied it with post-Marinoan cap carbonates globally.

More recent geochronological results from the Sete Lagoas Formation imply a potentially younger Ediacaran age. For example, detrital zircons from the Sete Lagoas Formation are as young as ca. $550 \mathrm{Ma}$, yielding a concordia age with the youngest grains of $592 \pm 1.7 \mathrm{Ma}$ (Paula-Santos et al., 2015). Warren et al (2014) recovered Cloudina fragments from the middle Sete Lagoas Formation near the city of Januária, in the north of Minas Gerais state, also implying a late Ediacaran age for the middle part of this formation towards the top of the Bambuí Group. These authors argued for a marine link between South America, Africa, and probably Antarctica that would have provided the ideal conditions for the Cloudina occurrence on the São Francisco craton. In contrast, Paula-Santos et al. (2015) argued that the Bambuí basin was confined and restricted from the open ocean to account for the discrepancy between middle to late Ediacaran detrital zircon ages and persistent ${ }^{87} \mathrm{Sr} /{ }^{86} \mathrm{Sr}$ ratios of $0.7074-0.7076$, which are typical of early Ediacaran rocks globally.

A middle-late Ediacaran age is also contradicted by K-Ar muscovite cooling ages of $588 \pm 15$ and $567 \pm 17 \mathrm{Ma}$ on nappes of the Brasília fold belt, which were thrust over the southwestern margin of the Bambuí basin, implying that the Bambuí Group predates the middle Ediacaran (Valeriano et al., 2000). Similarly, on the eastern São Francisco craton, the minimum depositional age is well constrained between 590 and 545 Ma from zircon crystallization ages of the syn-collisional G2 
1 granitic supersuite in the Araçuaí fold belt, which structurally affected the eastern margin of the

2 Bambuí basin (e.g. Pedrosa-Soares et al., 2001; Gonçalves et al., 2015). It is evident that different

3 datasets have yielded contradictory age constraints for the Bambuí Group, with very different

4 implications for the evolution of the São Francisco craton and Ediacaran Earth history. Despite those

5 complications, the emerging picture is one of deposition of the entire Bambuí Group from the Sete

6 Lagoas upwards during the Ediacaran Period, perhaps terminating at around $540 \mathrm{Ma}$ as suggested by the younger deformational ages of both the Brasília and Araçuaí fold belts.

\subsection{Jequitaí Formation}

The Jequitaí Formation outcrops in several regions, from the central São Francisco craton to the eastern margin of the Brasília fold belt (Fig. 1). At Serra da Água Fria, close to the Serra do Cabral, the Jequitaí Formation locally comprises the base of the Bambuí Group and is widely recognized as being of glacial origin (e.g.: Isotta et al., 1969; Uhlein et al., 1999, 2011b; Cukrov et $a l ., 2005)$. The Jequitaí Formation reaches thickness of $>150 \mathrm{~m}$ and is predominantly composed of massive diamictites. Very rare and narrow centimetre- to metre-scale alternations of sandstones and pelites in the Serra da Água Fria contrast with thicker siltstones intercalations and pebble-sized dropstones of quartzites in the Cristalina region (Fig. 3). The diamictites contain granules to large boulders, which are angular to sub-rounded and composed of sandstones, carbonates, pelites, granites and gneisses, vein quartz and diverse volcanic rocks. Isotta et al. (1969) discovered a striated pavement on sandstones in the Serra da Água Fria region. Later, Rocha-Campos et al. (1996) reinterpreted the glacial abrasion to have formed over a soft substrate beneath a marine ice sheet, implying a foreshore depositional setting (Uhlein et al., 1999, 2011b; Cukrov et al., 2005; see also Caxito et al. 2012). In the Cristalina region, the greater thickness of the Jequitaí Formation, occurrence of drospstones, and absence of striated pavements together imply a deep offshore environment (Cukrov et al., 2005) (Fig. 3).

Other diamictite occurrences in the Bezerra and Vila Boa regions (Fig. 1 and 3), below cap carbonates of the Sete Lagoas Formation, are unambiguously correlated with the Jequitaí Formation and suggest deposition in terminal moraines atop a basement of Mesoproterozoic Paranoá Group (Alvarenga et al., 2007, 2014; Martins-Ferreira, 2013). 

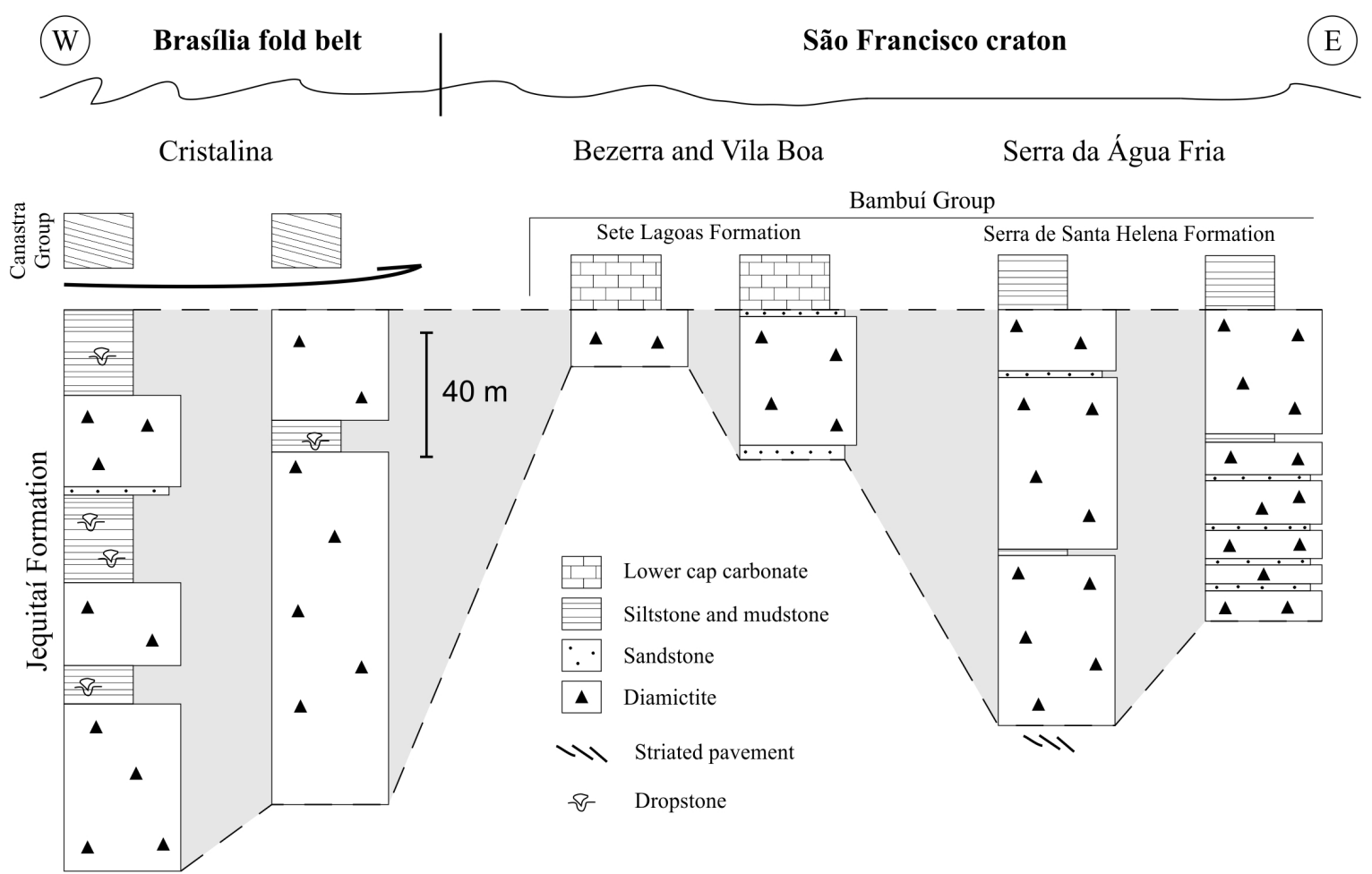

2 Fig. 3: Stratigraphic logs of the end-Cryogenian glaciogenic Jequitaí Formation plotted in a W-E 3 profile, from the Brasília fold belt to the undeformed São Francisco craton. The top of the Jequitai 4 Formation is used as the datum. Stratigraphic data from Uhlein et al. (1999, 2011b); Cukrov et al. 5 (2005); Alvarenga et al. (2007); Martins-Ferreira et al. (2013); Alvarenga et al. (2014). See Fig. 1 6 for locations.

\subsection{Carrancas Formation}

The Carrancas Formation is a conglomerate-bearing unit patchily preserved at the base of the Bambuí Group (Fig. 2). A type section of 20-30 meters of diamictites overlain by rhythmites and overlain sharply by basal Ediacaran cap carbonates of the Sete Lagoas Formation was established by Tuller et al. (2008) in the Inhaúma region for the Carrancas Formation.

The classic outcrop of the Carrancas Formation at the $30 \mathrm{~km}$ marker of the MG-424 road consists of a $3 \mathrm{~m}$-thick conglomerate with a sandy-calcareous matrix and pebble- to boulder-sized clasts of gneiss, dolostone, limestone, granite and quartz. Caxito et al. (2012) suggested that the calcite-rich matrix and the occurrence of carbonate clasts, with petrological and isotopic characteristics identical to the lower Sete Lagoas Formation, are most consistent with a derivation from local reworking of the basal carbonate platform, along with its basement. This interpretation clearly distinguishes the Carrancas Formation from the Jequitaí Formation chronologically, suggesting that it is a lateral equivalent of the cap carbonate that was formed by the shedding of cap carbonate debris deposited during the post-glacial transgression deposition. However, recent road cut exposures have revealed that the conglomerate at this classic outcrop sits atop a sharp contact with 
lower Sete Lagoas Formation carbonates. The paraconglomerate actually shows a lenticular geometry, and it is bound below and above by carbonates of the Sete Lagoas Formation. Thus, it is clear that this outcrop is not correlative with the Carrancas Formation proper, which strictly lies

4 below the Sete Lagoas Formation.

Although evidence for glacial influence on the Carrancas Formation is typically absent or equivocal, it was long considered to be glacial in origin (Martins-Neto et al., 2001; Sgarbi et al., 2003; Romano and Knauer, 2003; Romano, 2007; Ribeiro et al., 2008; Reis and Alkmim, 2015) and correlated with the Jequitaí Formation, which occurs basin-wide. Indeed, recent synthesis of detailed stratigraphic and sedimentary data from the southern Bambuí basin showed no evidence of glacial activity in the Carrancas Formation, which is instead interpreted as having been deposited in basement lows along fault margins (Vieira et al., 2007a,b; Uhlein et al., 2013). However, a more thorough definition of the Carrancas Formation and interpretation of its significance with respect to the early stages of the Bambuí basin deposition and its timing relative to the end-Cryogenian glaciation are required.

\section{SAMPLING AND ANALYTICAL PROCEDURES}

Care was taken to select the freshest samples, with a preference for fine-grained lithologies for all geochemical analyses. Following removal of any weathered and veined surfaces, samples were crushed in a jaw crusher, and a fraction of the resulting fragments was then pulverized in a ball mill.

Trace and rare earth elements analyses were performed by ACME Analytical Laboratories Ltd. (Vancouver, Canada). Concentrations were measured via ICP-MS after fusion with lithium metaborate / tetraborate and digestion with diluted nitric acid. Analytical errors are within 5\% for major and minor elements and $10-15 \%$ for trace elements. Loss on Ignition (LOI) was determined by weight loss after ignition at $1000^{\circ} \mathrm{C}$.

The Sm-Nd isotope analyses were conducted in Radiogenic Isotope Laboratory at GEOTOPUQÀM (Montréal, Canada). The samples were dissolved in an $\mathrm{HF}_{-} \mathrm{HNO}_{3}$ mixture in Teflon vessels in which a ${ }^{150} \mathrm{Nd}-{ }^{149} \mathrm{Sm}$ tracer was also added in order to determine $\mathrm{Nd}$ and Sm concentrations. Rare earth elements (REEs) were separated by cation exchange chromatography, and $\mathrm{Sm}$ and $\mathrm{Nd}$ were subsequently isolated following the procedure of Pin and Zalduegui (1997). The total procedural blanks are less than $150 \mathrm{pg}$. Sm and $\mathrm{Nd}$ analyses were performed using a double filament assembly on a Thermo Scientific Triton Plus mass spectrometer in static mode. The Sm and Nd concentrations and the ${ }^{147} \mathrm{Sm} /{ }^{144} \mathrm{Nd}$ ratios have an accuracy of $0.5 \%$ that corresponds to an average error on the 
initial $\varepsilon N d$ value of \pm 0.5 epsilon units, based on repeated measurements of standards JNdi and BHVO-2.

Carbon and oxygen isotope ratios were measured on a $\mathrm{Nu}$ Perspective dual-inlet isotope ratio mass spectrometer connected to a NuCarb carbonate preparation system in the McGill University Stable Isotope Laboratory (Montréal, Canada). Approximately $100 \mu \mathrm{g}$ of sample powder was weighed into glass vials and reacted individually with $\mathrm{H}_{3} \mathrm{PO}_{4}$ after heating to $90^{\circ} \mathrm{C}$ for 1 hour. The released $\mathrm{CO}_{2}$ was collected cryogenically and isotope ratios were measured against an in-house reference gas in dual inlet mode. Samples were calibrated to VPDB (Vienna Pee Dee Belemnite) using house standards. Errors better than $0.05 \%$ o $(1 \sigma)$ for both $\delta^{13} \mathrm{C}$ and $\delta^{18} \mathrm{O}$ based on repeat analyses of standards.

Zircon grains were analyzed at the Laboratório de Geocronologia, Universidade de Brasília, Brazil, by laser ablation on a Finnigan Neptune multi-collector ICP-MS coupled to a Nd-YAG 213 nm laser ablation system. The U-Pb analyses follow the procedures outlined in Bühn et al. (2009). Ablation was carried out using $25-30 \mu \mathrm{m}$ spots in raster mode, at a frequency of $9-13 \mathrm{~Hz}$ and intensity of $0.19-1.02 \mathrm{~J} / \mathrm{cm}^{2}$. The ablated material was carried by $\operatorname{Ar}(\sim 0.90 \mathrm{~L} / \mathrm{min})$ and $\mathrm{He}(\sim 0.40$ $\mathrm{L} / \mathrm{min}$ ) in 40 cycles of $1 \mathrm{~s}$ each, following a standard-sample bracketing of three sample analyses between a blank and a GJ-1 zircon standard. Accuracy was controlled using the TEMORA-2 standard. Raw data was reduced using an in-house program and corrections were done for background, instrumental mass bias and common $\mathrm{Pb}$. U-Pb ages were calculated using Isoplot 3.6 (Ludwig, 2008).

\section{RESULTS AND INTERPRETATIONS}

The Carrancas Formation overlies Archean-Paleoproterozoic granite-gneiss of the Belo Horizonte Complex and Neoarchean meta-volcano-sedimentary rocks of the Rio das Velhas Supergroup. Both units are part of the uplifted cratonic basement that forms the Sete Lagoas paleohigh on the southern São Francisco Craton (e.g. Teixeira et al, 2000; Alkmim, 2004) (Fig. 2). Here we summarize the stratigraphic, sedimentological, isotopic $\left(\delta^{13} \mathrm{C}, \delta^{18} \mathrm{O}\right)$ and geochronological $(\mathrm{Sm}-$ $\mathrm{Nd}, \mathrm{U}-\mathrm{Pb}$ ) records in the Carrancas Formation outcrop areas. Four facies associations are described from these areas (Table 1 and Fig. 2): clast- to matrix-supported conglomerates and breccias (FA1); coarse to fine-grained sandstone (FA2); mudstone and siltstone with black shale (FA3), and sandysiltstone and dolostone (FA4).

\subsection{Sedimentological and stratigraphic analyses of the Carrancas Formation}


The Carrancas Formation in the Pitangui area overlaps metasedimentary rocks (mainly micaschist and quartzite) of the Neoarchean Rio das Velhas Supergroup (Fig. 2) and is composed of clastsupported conglomerates, breccias and diamictites at the base (FA1) passing gradually upward to coarse- to fine-grained sandstones (FA2) (Fig. 4A and 5). The matrix consists of fine-sand to silty quartz, and the dominant clast lithologies derive from the local basement comprising the metavolcano-sedimentary Rio das Velhas Supergroup: quartzite, granitoid, gneiss, schist, quartz pebbles and chert. Dolomite clasts from an unknown source are also present. Clasts range from small pebbles to large boulders in size and are angular to sub-rounded. Clast size and clast/matrix ratio gradually decrease toward the top until diamictite layers predominate. The diamictite contains small-pebbles of carbonate, quartzite, schist and chert, along with small $(0.2 \mathrm{~cm})$ limonitized pyrite scattered through a matrix composed by clay minerals and silt to fine-sand quartz.

Above and laterally conglomerates and diamictites, massive conglomeratic sandstones occur, with locally pebbles of quartz and schist. They are rarely intercalated with normal graded, finegrained sandstones and with small-scale tabular cross-stratification. We interpret coarse-grained sedimentary rocks and sandstones to represent deposition on alluvial fan, from proximal to distal fan, respectively, likely as a result of local block faulting and basement uplift.

Mudstones, siltstones and rhythmites of FA3 (Table 1) variably overlie basement rocks, FA1 and FA2. Mudstones are interbedded with ferruginous siltstones and black shales, which have total organic contents (TOC) of up to $1.5 \%$ (Fig. 5). These facies commonly pass from ferruginous siltstones up into black shale, and mud-silt couplets (rhythmites) are commonly intercalated in with massive mudstones. These facies are widespread and common in all studied areas.

Upsection, a gradual increase in the abundance of sand-sized grains, eventually transitioning into sandy-siltstones beds, which also contain dolomitic grains. Bedded and laminated dolomitic sandy-siltstone with common hummocky cross-stratification occurs below an overlying transitional contact with reddish dolomites. Bedded and finely laminated reddish dolomite form a unit $\sim 15 \mathrm{~m}$ thick locally show low-angle tabular cross-stratification and small-scale wave ripples (dolarenite), interbedded with thin $(2-5 \mathrm{~cm})$ beds of greenish siltstone (Fig. 4A, 4B and 5). The dolomitic sandysiltstone with hummocky cross-stratification below dolomites with wave ripples suggest deposition in a shallower depositional setting influenced by tidal currents.

In the Pitangui area, the quartzites and metaconglomerates of the Rio das Velhas Supergroup outcrop at higher elevations, while the lithofacies of the Carrancas Formation are all limited to 
1 topographic lows. The stratigraphy seems to track the present geography, with thicker intervals of the

2 clast-supported conglomerates, breccias and diamictites close to topographic highs.

3 Table 1: Facies associations of the Carrancas Formation in studied areas. See text for details and 4 occurrences in each area.

\begin{tabular}{|c|c|c|c|c|c|}
\hline $\begin{array}{c}\text { Facies } \\
\text { association }\end{array}$ & Facies & $\begin{array}{c}\text { Sedimentary } \\
\text { structures }\end{array}$ & Other characteristics & $\begin{array}{l}\text { Depositional } \\
\text { setting }\end{array}$ & Processes \\
\hline \multirow{3}{*}{ FA1 } & $\begin{array}{l}\text { Cast-supported } \\
\text { breccia }\end{array}$ & $\begin{array}{c}\text { Massive, rarely } \\
\text { layered }\end{array}$ & \multirow{2}{*}{$\begin{array}{l}\text { Sandy matrix. Granule to } \\
\text { boulder in size clasts sampling } \\
\text { local basement and from area to } \\
\text { area. Locally carbonates } \\
\text { intraclasts. }\end{array}$} & \multirow{3}{*}{ Alluvial fan } & \multirow{3}{*}{ Debris/mud flows } \\
\hline & $\begin{array}{l}\text { Clast-supported } \\
\text { conglomerate }\end{array}$ & Massive & & & \\
\hline & Diamictite & Massive & $\begin{array}{l}\text { Mud-silt greenish matrix. } \\
\text { Pebble-sized clasts of siltstone } \\
\text { and carbonate }\end{array}$ & & \\
\hline \multirow[t]{2}{*}{ FA2 } & $\begin{array}{l}\text { Fine-grained } \\
\text { sandstone }\end{array}$ & $\begin{array}{c}\text { Layered; } \\
\text { normally graded } \\
\text { beds; tabular } \\
\text { cross } \\
\text { stratification }\end{array}$ & Greenish when fresh. & \multirow{2}{*}{$\begin{array}{l}\text { Distal alluvial } \\
\text { fan; fan } \\
\text { channels }\end{array}$} & \multirow[t]{2}{*}{$\begin{array}{l}\text { Hyperconcentrated to } \\
\text { normal stream flows. }\end{array}$} \\
\hline & $\begin{array}{l}\text { Coarse-grained } \\
\text { sandstone }\end{array}$ & Massive & $\begin{array}{c}\text { Greenish when fresh; locally } \\
\text { conglomeratic with siltstone and } \\
\text { quartz pebbles }\end{array}$ & & \\
\hline \multirow{4}{*}{ FA3 } & Mudstone & $\begin{array}{l}\text { Massive; } \\
\text { laminated }\end{array}$ & White silky mudstone & \multirow{4}{*}{$\begin{array}{l}\text { Deep marine; } \\
\text { below wave- } \\
\text { level }\end{array}$} & Suspended load \\
\hline & Black shale & Fissility & 0.5 to $1.5 \%$ TOC & & $\begin{array}{l}\text { Suspended load and } \\
\text { organic productivity }\end{array}$ \\
\hline & Siltstone & Laminated & $\begin{array}{l}\text { Pale yellow; reddish when rich } \\
\text { in iron oxi-hydroxide minerals. }\end{array}$ & & \multirow{2}{*}{$\begin{array}{l}\text { Suspended load and } \\
\text { tractive currents }\end{array}$} \\
\hline & Rhythmite & Laminated & Silt to mud & & \\
\hline \multirow[b]{3}{*}{ FA4 } & Sandy-siltstone & $\begin{array}{c}\text { Bedded; } \\
\text { Hummocky }\end{array}$ & $\begin{array}{l}\text { Greenish when fresh; dolomitic } \\
\text { to the top }\end{array}$ & \multirow[b]{3}{*}{$\begin{array}{l}\text { Shallow to } \\
\text { mid-marine; } \\
\text { above wave- } \\
\text { level }\end{array}$} & \multirow{2}{*}{$\begin{array}{l}\text { Storm-weather waves } \\
\text { and tractive currents }\end{array}$} \\
\hline & Siltstone & Laminated & Greenish & & \\
\hline & Dolostone & $\begin{array}{c}\text { Massive; } \\
\text { layered; } \\
\text { low-angle cross } \\
\text { stratification; } \\
\text { small-scale } \\
\text { wave ripples }\end{array}$ & $\begin{array}{c}\delta^{13} \mathrm{C}=+7.1 \text { to }+9.6 \% \text { } \\
\delta^{18} \mathrm{O}=-6.9 \text { to }-5.2 \%\end{array}$ & & $\begin{array}{l}\text { Precipitation; Fair- } \\
\text { weather waves; } \\
\text { Bedload transport }\end{array}$ \\
\hline
\end{tabular}




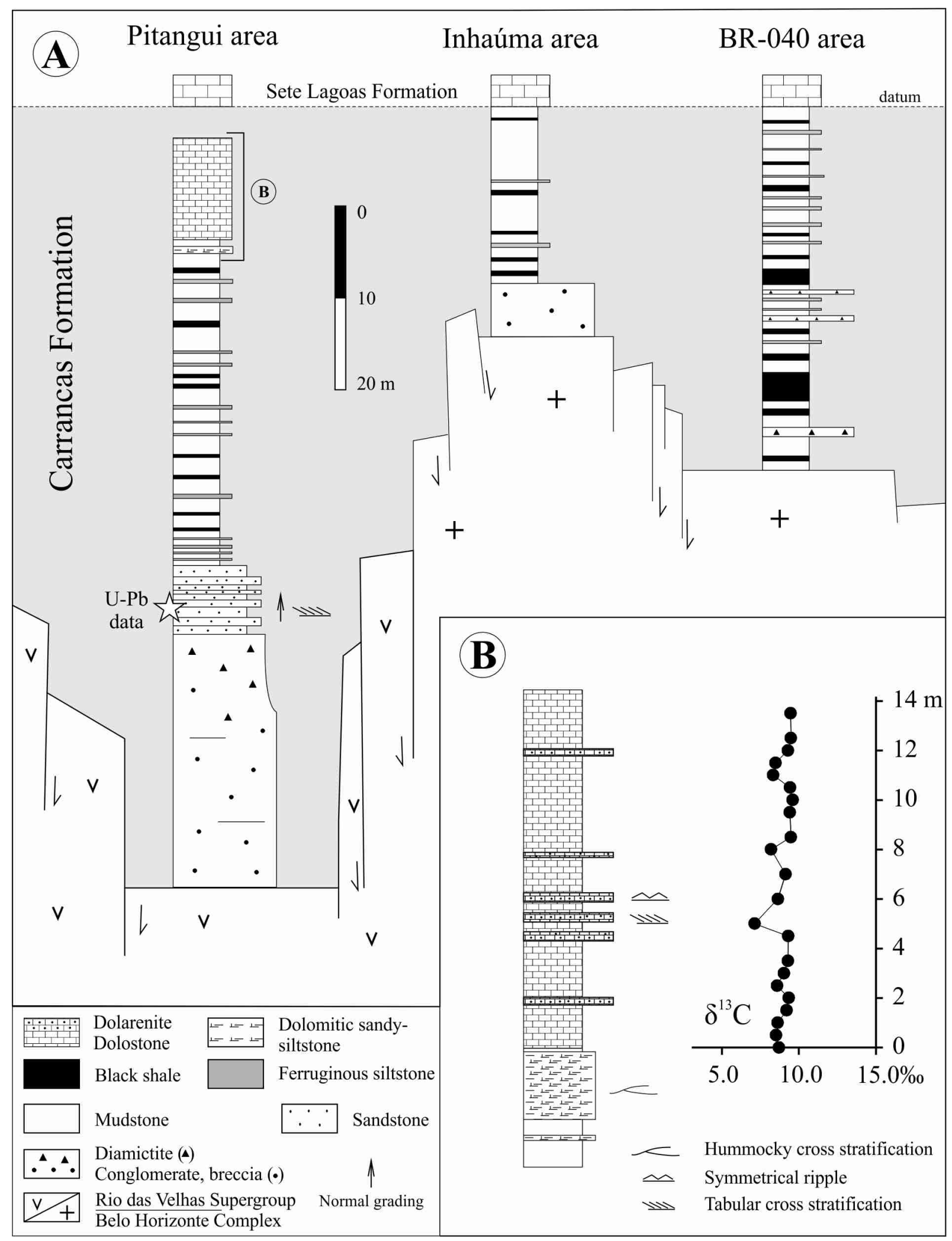

Fig. 4: A - Stratigraphic sections and paleogeographic interpretation of the three studied areas of the 3 Carrancas Formation. The datum for all sections is the base of the Sete Lagoas Formation. See text 4 for stratigraphic details. Not in horizontal scale. B - Detail of the transition from mudstones and 5 siltstones (FA3) to dolomitic sandy-siltstones and dolomites (FA4), along with C isotopic profile of 6 the reddish dolomite layers. FA: Facies Association (Table 1). 
4.1.2. Inhaúma area

The Carrancas Formation overlies Archean/Paleoproterozoic gneisses of the Belo Horizonte complex near the cities of Inhaúma and Sete Lagoas (Fig. 2 and 4). The outcrop area is limited to a few square kilometers with 5 meters of clast-supported conglomerate (FA1) capped directly by 20 $\mathrm{m}$ of grey and white siltstone and mudstone (FA3), which is in turn overlain by bedded limestones of the Sete Lagoas Formation. The conglomerate contains exclusively pebble-sized, angular to subrounded, gneiss and granite clasts embedded in a quartz-feldspar sandy matrix (Fig. 5). The nearly monolithic clast assemblage and feldspatic matrix suggest a local source area for the Inhaúma conglomerates.

In the BR-040 area (Fig. 2 and 4), the Carrancas Formation onlaps Archean/Paleoproterozoic gneisses of the Belo Horizonte complex and is predominantly composed of mudstones with intercalations of ferruginous siltstones and black shales (FA3; Table 1). Black shales are much more common here than any other area. Locally, thin $(\sim 20 \mathrm{~cm})$ diamictite beds containing granules to small pebble-sized clasts occur within the mudstones. Five meters of well bedded Sete Lagoas Formation limestones featuring low-angle cross stratification occur above a sharp contact with the Carrancas Formation.

\subsection{Depositional setting of the Carrancas Formation}

Stratigraphic and sedimentological data acquired from the three different areas provide a basis for establishing a simple depositional framework for the Carrancas Formation. The lower Carrancas Formations consists of poorly organized gravitationally deposited sediments localized along fault scarps, with alluvial fan conglomerates and diamictites passing upward and laterally into conglomeratic to fine-grained sandstones deposited in fan channels by hyperconcentrated flows, which are best represented in the Pitangui area (Fig. 4). These two facies associations (FA1 and FA2; Table 1) represent a phase of continental rift phase and graben filling.

The upward transition to finer-grained sediments, including mudstones, black shales and ferruginous siltstones, marks an abrupt transgression which flooded local basement highs and 
1 resulted in onlap and draping of the previously established topography, in response to active phase of

2 rifting and high rates of subsidence (Fig. 4). FA3 is the only facies association that occur in all areas and has sedimentary facies not common in any other Bambui Group unit, thus it is an efficient

4 marker unit for correlation between areas and clearly marks an important transgressive surface

5 during Carrancas Formation deposition.

Sedimentation rates then outpaced subsidence rates, resulting in an upward-shallowing succession and occurrence of shallow marine facies and gradual increase in carbonate content.

8 Symmetrical ripples and small-scale (30 cm high) tabular cross beds in the uppermost dolarenites imply deposition in a shallow, fair-weather wave setting with episodic currents (Fig. 4).

In both the Inhaúma and BR-040 areas, the Carrancas Formation is found in contact with Paleoproterozoic (ca. $2.2 \mathrm{Ga}$ ) amphibolite and metadiabase dykes. According to Chaves and Neves (2005), dyke emplacement (the Paraopeba swarm) and deformation took place inside vertical transcurrent shear zones developed during the Paleoproterozoic $(2.0 \pm 0.2 \mathrm{Ga})$ orogeny. Later reactivation of these transcurrent shear zones into brittle normal faults is suggested by the cataclastic and strongly fractured nature of the dykes, indicating minor extension of the São Francisco crust (Chaves and Neves, 2005). We suggest that this extensional event may be related to deposition of the Carrancas Formation. Furthermore, a syn-rift model for the Carrancas Formation is corroborated by other data. First, the basal conglomerates and diamictites comprise locally derived clasts. Second, the highly variable thickness of stratigraphic units and facies, including thickening of conglomerates near inferred basement highs and pinch-out into basement lows, suggests development of horsts and grabens.

The Carrancas Formation onlaps the basement in all areas and its conglomerates were deposited inside grabens adjacent to rift shoulders, with distal fan channels deposition, suspended load settling, and bedload transport influenced by storm- to fair-weather waves and episodic bottom currents, during a single transgressive-regressive sequence. The limited thickness of the Carrancas Formation $(<80 \mathrm{~m})$ and its highly localized preservation suggest that this extensional event was minor and maybe restricted to the southern São Francisco craton. 

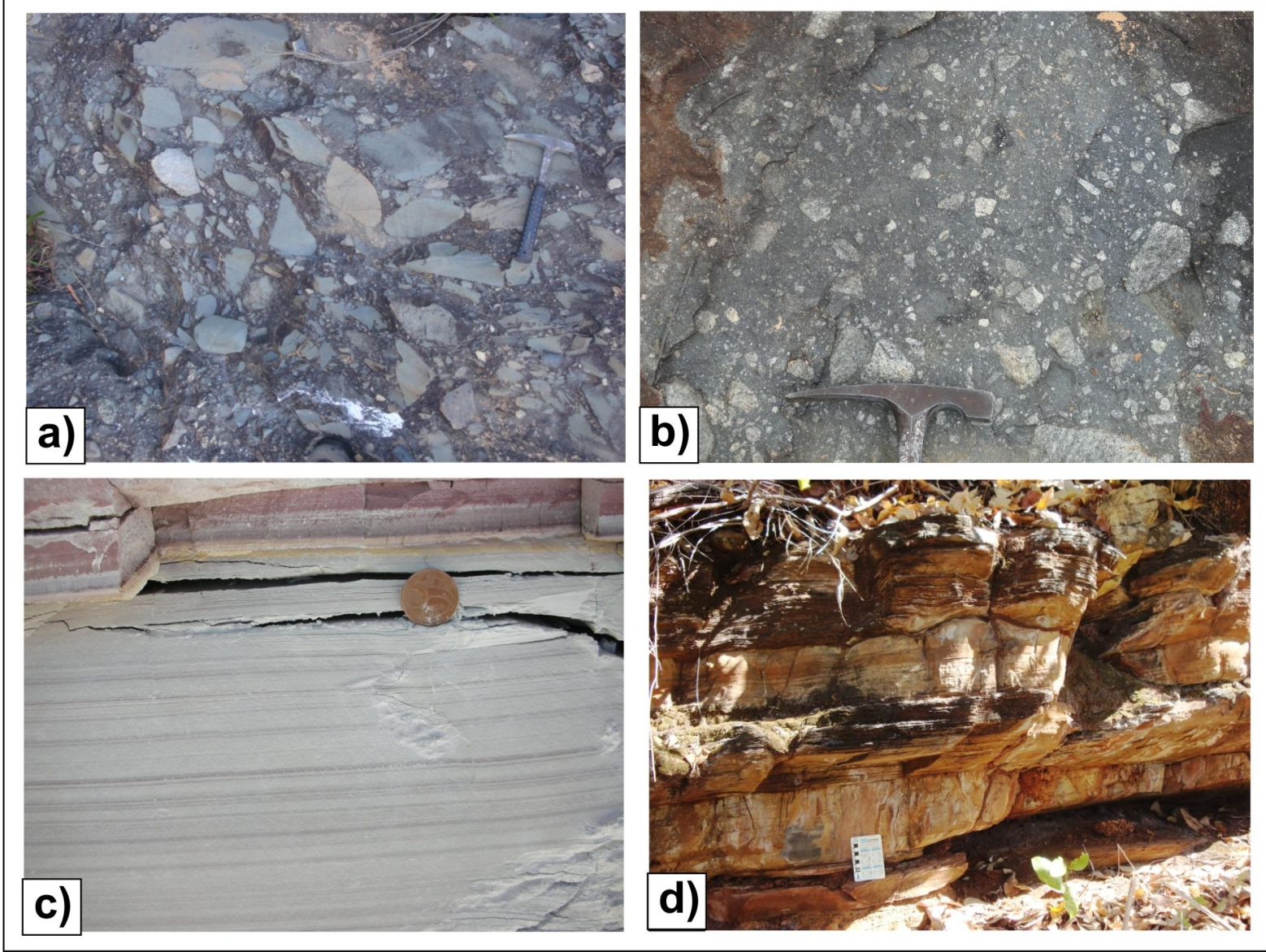

Fig. 5: Lithotypes of the Carrancas Formation in studied areas. (a) Clast-supported conglomerate with angular to sub-angular quartzite clasts; (b) Clast-supported conglomerate composed exclusively of gneissic and granitic clasts. (c) Ferruginous siltstone lamina and layers intercalated within white mudstone; (d) Bedded and finely laminated reddish dolostone.

\subsection{Sedimentary provenance}

\subsubsection{Trace and rare earth elements of Carrancas Formation lithotypes}

Ten samples of the Carrancas Formation were analyzed for trace and rare earth elements. Four samples were collected in the BR-040 areas, and six are from the Pitangui area (Table 2).

The chondrite-normalized REE (Rare Earth Element) data (Boynton, 1984 - Fig. 6a) show a similar pattern for almost all samples, with moderate enrichment of the light rare earth elements (LREEs) in comparison with the heavy rare earth elements (HREEs), as quantified by the chondritenormalized ratio of $\mathrm{La}_{\mathrm{n}} / \mathrm{Yb}_{\mathrm{n}}$ (1.3-11.3). The samples also show a consistent negative Eu anomaly $\left(\mathrm{Eu} / \mathrm{Eu}^{*}=0.43\right.$ to 0.75$)$. Samples OP-12 and OP-01 are less REE-enriched, with $\Sigma$ REE of 35.6 and $51.6 \mathrm{ppm}$, respectively. In contrast, the remaining samples show $\Sigma$ REE of 127.4-293.2 ppm. The REE $+Y$ data were normalized to the Post-Archean Australian Shale composition (PAAS from Taylor and Mclennan, 1985) and show a roughly flat pattern for all samples (Fig. 6b), except for samples 
1 OP01 and OP12. Samples from the BR-040 area are more REE+Y enriched then samples from the

2 Pitangui area.

3 Table 2: Major and trace elements of the Carrancas Formation in Pitangui and BR-040 areas. BS:

4 black shale; FS: ferruginous siltstone; Silt: siltstone; FSand: Fine-grained sadstone; CSC: clast-

5 supported conglomerate (matrix).

\begin{tabular}{|c|c|c|c|c|c|c|c|c|c|c|}
\hline Sample & P05 B & P05 M & P 16 & P 02 & OP 99 & OP 100 & OP 01 & OP 07 & OP 171 & OP 188 \\
\hline Facies & BS & BS & Silt & FS & Silt & Silt & FS & FSand & FSand & $\mathrm{CSC}$ \\
\hline Area & BR-040 & BR-040 & BR-040 & BR-040 & Pitangui & Pitangui & Pitangui & Pitangui & Pitangui & Pitangui \\
\hline $\mathrm{Cr}(\mathrm{ppm})$ & 102.6 & 102.6 & 109.4 & 116.3 & 88.9 & 150.5 & 150.5 & 280.4 & 88.9 & 259.9 \\
\hline Y & 37.6 & 48.1 & 36.3 & 55.5 & 30.8 & 13.5 & 8.6 & 22.4 & 48.3 & 36.7 \\
\hline Th & 14.5 & 13.8 & 15.1 & 15.1 & 8.9 & 10.2 & 6 & 9.7 & 12.7 & 6.5 \\
\hline $\mathrm{Ni}$ & 20 & 3.7 & 10.3 & 4.4 & 37.9 & 52.6 & 6 & 218.6 & 62.9 & 108.6 \\
\hline $\mathrm{Sc}$ & 19 & 20 & 19 & 19 & 17 & 17 & 11 & 18 & 16 & 12 \\
\hline Co & 1.5 & 1.1 & 1.8 & 1.4 & 14.2 & 5.6 & 1.5 & 23.3 & 19.9 & 26.8 \\
\hline $\mathrm{La}$ & 33.9 & 62.5 & 42.6 & 37.3 & 32.2 & 28 & 8.3 & 35.3 & 57.2 & 28.5 \\
\hline $\mathrm{Ce}$ & 66.5 & 107.3 & 69.8 & 64.7 & 56.8 & 59.4 & 19 & 50.4 & 83.6 & 80.7 \\
\hline $\operatorname{Pr}$ & 9.3 & 15.83 & 10.41 & 8.57 & 7.6 & 5.66 & 2.47 & 6.46 & 11.52 & 7.4 \\
\hline $\mathrm{Nd}$ & 35.1 & 61.3 & 39.9 & 32.9 & 32.4 & 19.6 & 11.1 & 20.2 & 42.6 & 26.1 \\
\hline $\mathrm{Sm}$ & 7.5 & 11.81 & 7.91 & 6.38 & 5.86 & 3.89 & 2.69 & 3.72 & 8.61 & 5.19 \\
\hline $\mathrm{Eu}$ & 1.35 & 2.15 & 1.54 & 1.37 & 1.31 & 0.55 & 0.59 & 0.97 & 1.66 & 1.31 \\
\hline $\mathrm{Gd}$ & 7.27 & 10.09 & 7.71 & 7.07 & 5.87 & 2.98 & 2.49 & 3.63 & 8.21 & 4.71 \\
\hline $\mathrm{Tb}$ & 1.07 & 1.39 & 1.13 & 1.2 & 0.86 & 0.41 & 0.35 & 0.66 & 1.18 & 0.85 \\
\hline Dy & 6.81 & 7.9 & 6.69 & 8.63 & 5.34 & 2.26 & 1.98 & 3.98 & 7.01 & 5.59 \\
\hline Ho & 1.35 & 1.65 & 1.25 & 1.94 & 1.11 & 0.56 & 0.34 & 0.81 & 1.37 & 1.11 \\
\hline $\mathrm{Er}$ & 3.78 & 4.89 & 3.59 & 5.26 & 3.2 & 1.86 & 0.98 & 2.26 & 3.95 & 3.64 \\
\hline $\mathrm{Tm}$ & 0.58 & 0.78 & 0.57 & 0.81 & 0.45 & 0.29 & 0.15 & 0.35 & 0.59 & 0.62 \\
\hline $\mathrm{Yb}$ & 3.78 & 4.78 & 3.53 & 5.71 & 2.86 & 1.67 & 0.98 & 2.14 & 3.74 & 3.91 \\
\hline $\mathrm{Lu}$ & 0.6 & 0.8 & 0.56 & 0.84 & 0.43 & 0.29 & 0.14 & 0.33 & 0.56 & 0.56 \\
\hline
\end{tabular}

A plot of $\mathrm{Co} / \mathrm{Th}$ vs. La/Sc distinguishes the Pitangui shales as having relatively high $\mathrm{Co} / \mathrm{Th}$ 8 ratios and low $\mathrm{La} / \mathrm{Sc}$ ratios, consistent a contribution of mafic provenance to these shales (Fig. 6c).

$9 \mathrm{The} \mathrm{Al}_{2} \mathrm{O}_{3} / \mathrm{TiO}_{2}$ ratios of the investigated shales range from 20 to 21 for the BR-040 area (average 10 20.7) and 13 to 27 for the Pitangui area (average 17.7). Based on the work of Girty et al. (1996), 11 these ranges imply that fine-grained sediments were derived predominantly from intermediate 12 igneous rocks, but with some degree of mafic addition, especially in the Pitangui area. 
The medium to high contents of $\mathrm{Cr}(88-288$, average $=143 \mathrm{ppm})$ and $\mathrm{Ni}(4-218$, average $=$

$258 \mathrm{ppm}$ ) in the studied shales are consistent with a component of mafic and ultramafic provenance.

3 During the Archean the concentration of these elements was higher than in Post-Archean-type rocks.

4 (e.g.: Condie, 1993). Hence, Taylor and McLennan (1985) correlate the higher concentrations of $\mathrm{Cr}$

5 and $\mathrm{Ni}$ in some sedimentary rocks with Archean provenances and use these concentrations to

6 discriminate between Archean and post-Archean source areas (Fig. 6d). The higher contents of $\mathrm{Cr}$

7 and $\mathrm{Ni}$ in shales from the PTA compared to the BRTA is probably due to the erosion of mafic-

8 ultramafic rocks in the meta-volcano-sedimentary Archean Rio das Velhas Supergroup basement,

9 which is found only in the Pitangui area.

Distinct whole rock geochemical data between the different areas is consistent with variable compositions from local sources areas and limited mixing of sediments derived from these local sources.
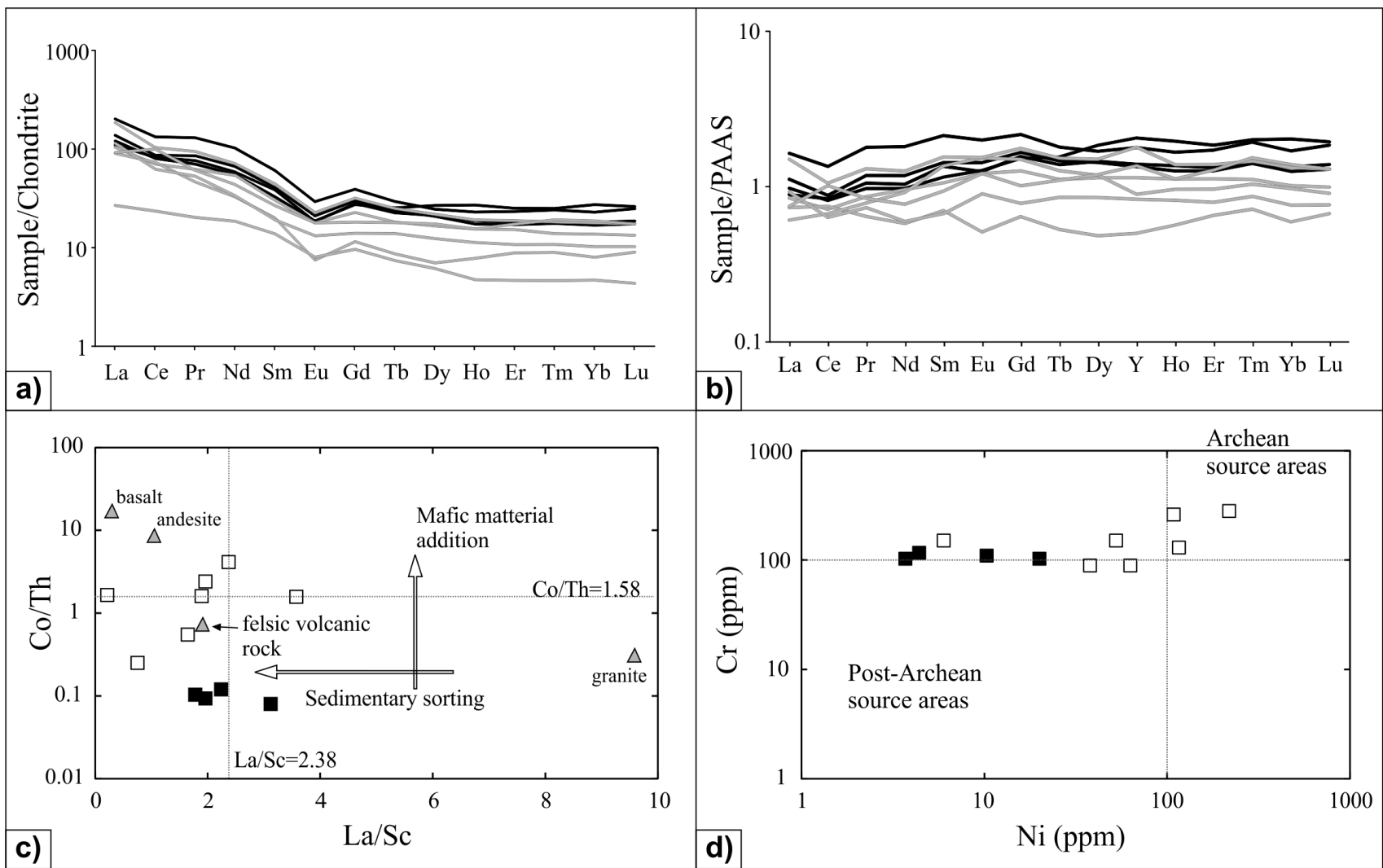

Fig. 6: REE data normalized to chondrite (a), from Boynton (1984) and PAAS (b) from McLennan (1989). Grey lines - Pitangui area; Black lines - BR-040 area; (c) La/Sc vs. Co/Th. The dotted lines represent PAAS values (Taylor and McLennan 1985); (d) Ni-Cr binary diagram. Archean and PostArchean fields from Taylor and McLennan (1985). White squares - Pitangui area; black squares BR-040 area. 
The results for the Sm-Nd data are presented in Table 3. Initial isotope ratios were calculated

2 at $660 \mathrm{Ma}$, as an approximation of a pre-Marinoan age. The fine-grained lithotypes from the

3 Carrancas Formation fall into two groups based on their $\mathrm{T}_{\mathrm{DM}}$ model ages and $\varepsilon \mathrm{Nd}_{(660 \mathrm{Ma})}$ : one with

4 model ages ranging from 1.7 to $2.1 \mathrm{Ga}$ and $\varepsilon \mathrm{Nd}_{(660 \mathrm{Ma})}$ between -5.9 to -7.8 ; and another group with

5 older $\mathrm{T}_{\mathrm{DM}}(2.8-3.0 \mathrm{Ga})$ and more evolved $\varepsilon \mathrm{Nd}_{(660 \mathrm{Ma})}(-17.7$ to -21.6$)$.

6

7 Table 3: Sm and $\mathrm{Nd}$ isotope data from Carrancas Formation. $\mathrm{T}_{\mathrm{DM}}$ model ages were calculated

8 following Goldstein et al. (1984). BS: black shale; FS: ferruginous siltstone; Silt: siltstone; CSC:

9 clast-supported conglomerate (matrix). $\mathrm{T}_{\mathrm{DM}}$ was not calculated for samples with very high

$10 \quad{ }^{147} \mathrm{Sm} /{ }^{144} \mathrm{Nd}$.

\begin{tabular}{|c|c|c|c|c|c|c|c|c|c|}
\hline Sample ID & Rock & $\begin{array}{c}\text { Nd } \\
(\mathrm{ppm})\end{array}$ & $\begin{array}{c}\text { Sm } \\
(\mathrm{ppm})\end{array}$ & ${ }^{147} \mathrm{Sm} /{ }^{144} \mathrm{Nd}$ & ${ }^{143} \mathbf{N d} /{ }^{144} \mathrm{Nd} \pm 2 \sigma$ & $\operatorname{eNd}_{(0)}$ & $\varepsilon \mathrm{Nd}_{(660 \mathrm{Ma})}$ & $\mathbf{T}_{\mathrm{DM}}$ & $f(\mathrm{Sm} / \mathrm{Nd})$ \\
\hline \multicolumn{10}{|l|}{ BR-040 Area } \\
\hline P-05-G & BS & 60.3 & 11.9 & 0.1194 & $0.511895 \pm 09$ & -14.5 & -7.8 & 2.03 & -0.39 \\
\hline OP5-7.5 & BS & 50.0 & 11.3 & 0.1365 & $0.511904 \pm 09$ & -14.3 & -9.1 & 2.5 & -0.31 \\
\hline OP5-4.5 & BS & 31.8 & 7.9 & 0.1499 & $0.511950 \pm 14$ & -13.4 & -9.4 & - & -0.24 \\
\hline OP5-3 & BS & 45.2 & 11.1 & 0.1489 & $0.511974 \pm 14$ & -12.9 & -8.8 & - & -0.24 \\
\hline BS - 4 & BS & 29.0 & 7.9 & 0.1650 & $0.511976 \pm 12$ & -12.9 & -10.2 & - & -0.16 \\
\hline BS-2 & BS & 34.9 & 8.9 & 0.1555 & $0.511954 \pm 16$ & -13.3 & -9.8 & - & -0.21 \\
\hline P-16 & Silt & 46.2 & 9.1 & 0.1201 & $0.511945 \pm 08$ & -13.5 & -6.9 & 1.96 & -0.39 \\
\hline P-02 & FS & 13.9 & 2.9 & 0.1290 & $0.511968 \pm 13$ & -13.1 & -7.2 & 2.12 & -0.34 \\
\hline
\end{tabular}

Pitangui Area

\begin{tabular}{cccccccccc} 
OP-100 & Silt & 19.9 & 3.6 & 0.1094 & $0.511144 \pm 08$ & -29.1 & -21.6 & 2.92 & -0.44 \\
OP-99 & Silt & 22.2 & 4.6 & 0.1251 & $0.511412 \pm 08$ & -23.9 & -17.7 & 2.98 & -0.36 \\
OP-88 & CSC & 40.3 & 7.8 & 0.1177 & $0.511358 \pm 09$ & -25.0 & -18.1 & 2.83 & -0.40 \\
OP-49A & Silt & 67.5 & 12.5 & 0.1121 & $0.511956 \pm 09$ & -13.3 & -5.9 & 1.79 & -0.43 \\
OP-171 & Silt & 63.4 & 10.9 & 0.1043 & $0.511895 \pm 10$ & -14.5 & -6.5 & 1.75 & -0.47 \\
OP-01 & FS & 6.83 & 1.71 & 0.1518 & $0.512060 \pm 10$ & -11.3 & -7.4 & - & -0.23 \\
\hline
\end{tabular}

11

Post-depositional fractionation of $\mathrm{Sm} / \mathrm{Nd}$ can result in higher ${ }^{147} \mathrm{Sm} /{ }^{144} \mathrm{Nd}$ ratios and hence higher $\mathrm{T}_{\mathrm{DM}}$ model ages. However, the ${ }^{147} \mathrm{Sm} /{ }^{144} \mathrm{Nd}$ ratios for the three samples with higher $\mathrm{T}_{\mathrm{DM}}$ ages are consistent with average crustal values (Goldstein et al., 1984) suggesting that these Nd model ages are reliable (Table 3). On the other hand, some of the black shales and sample OP-01 have anomalously high ${ }^{147} \mathrm{Sm} /{ }^{144} \mathrm{Nd}$ ratios, rendering the model age for these samples suspect.

The Nd isotope compositions of the Pitangui and BR-040 areas share similar patterns, except for three samples of the Pitangui area (Fig. 7). Excluding the three samples with different isotopic signals, the samples of the two studied areas overlap to some degree, suggesting similar source areas for the fine-grained rocks in both areas. In the diagrams of Fig. 7 these samples are outliers of the 
most probable source areas fields, which are inferred to be the Archean Rio das Velhas Supergroup (RV; David, 2011) and the Archean-Paleoproterozoic granite-gneiss cratonic basement (CB; Noce et al., 2000). Mixing of these two proposed sources along with a third source rock with a younger $\mathrm{Nd}$ isotope signature must be considered. A similar scenario has been inferred for fine-grained rocks in the upper Bambuí Group (e.g. Rodrigues, 2008; Pimentel et al., 2011). Although a source area with such a young $\mathrm{Nd}$ isotope signature is not present in the southern basement of the São Francisco Craton (Teixeira et al., 1996, 2000; Noce et al., 2000), it is quite common in the Brasília fold belt, on the western margin of the Bambuí Group (e.g.: Pimentel et al., 2000, 2001).

It is well established that the Brasília fold belt was one of the main source areas to the Bambuí basin. For comparison, the diagram in Figure 8 presents one additional possible source area for the sediments of the Carrancas Formation: the early to middle volcanic sequences of the Neoproterozoic Goiás Magmatic Arc (ca. 900-750 Ma) (GMA; Pimentel et al., 2000). These plots suggest a relationship between the $\mathrm{Sm}-\mathrm{Nd}$ data from the Carrancas Formation and the probable mixing between these three proposed source areas. Specific source areas for outlier samples remain unclear. We suggest that the southern basement of the São Francisco craton, with significant additions of younger arc-related rocks from the Brasília fold belt, make up the main sediment source for the fine-grained rocks of the Carrancas Formation. The isotopic composition represents the variable mixing of these two composite end-members.

The three other samples with older $\mathrm{Nd}$ model ages and more negative $\varepsilon \mathrm{Nd}_{(660 \mathrm{Ma})}$ values plot within the granite-gneiss CB and near the Rio das Velhas Supergroup (RV) fields and clearly show a different provenance than the other samples (Fig. 7). For these samples, a single local provenance is more logical, as implied by the high proportion of local, angular clasts in the nearby breccias. Hence, in contrast with the majority of the shales from the Carrancas Formation, the source sediment of these three samples was exclusively derived from Archean-Paleoproterozoic southern basement of the São Francisco Craton. Similarly, two black shales from the BR-040 area also share older $\mathrm{T}_{\mathrm{DM}}$ ages $(2.0$ and $2.5 \mathrm{Ga})$, but with less evolved $\varepsilon \mathrm{Nd}_{(660 \mathrm{Ma})}(-7.8$ and -9.1$)$.

Fig. 7d compares $\mathrm{Nd}$ model ages of the Carrancas Formation with data from the Bambuí Group (Pimentel et al. 2001). The Bambuí Group shows a narrower, younger, and more continuous range in $\mathrm{Nd}$ model ages than the Carrancas Formation. Thus, the sediments comprising the Carrancas Formation were heterogeneously sourced. This is consistent with stratigraphic and lithochemical data, and the polymodal data suggest that these sources may have been widely separated and that the sediments did not have the chance to become fully mixed on their way to the Carrancas sedimentary basins. 

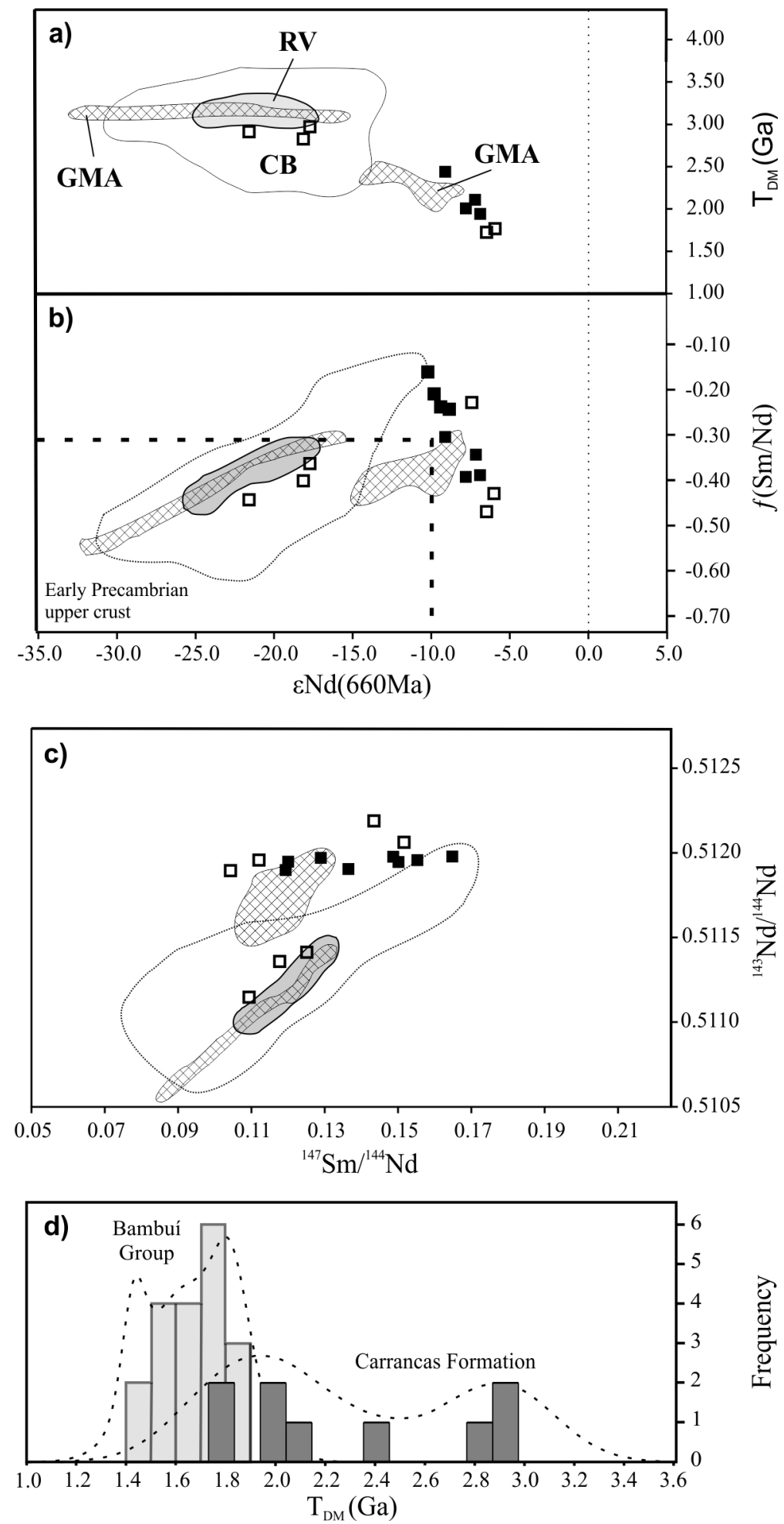

2 Fig. 7: Comparative plots of $\mathrm{Nd}$ isotopic characteristics of fine-grained rocks of the Carrancas 3 Formation and frequency histogram of $\mathrm{Nd}$ model ages. A, B, C) Pitangui area: white squares; BR4040 area: black squares. The limiting fields represent possible source areas: CB - granite-gneiss 5 cratonic basement (Noce et al., 2000); RV - Rio das Velhas Supergroup (David, 2011); GMA 6 Goiás Magmatic Arc (Pimentel et al., 2000). Early Precambrian upper crust field from McLennan 7 and Hemming (1992). The compiled data were recalculated for $\varepsilon \mathrm{Nd}_{(660 \mathrm{Ma})}$. D) Frequency histogram 8 and probability curve of $\mathrm{Nd}$ model ages for the Bambuí Group lithotypes (from Pimentel et al., 9 2001), and Nd model ages for the Carrancas Formation in Pitangui and BR-040 areas. 
A total of 53 zircon grains were extracted from a sandstone sample in the Pitangui area and analyzed by LA-ICP-MS, but only a subset of 26 zircons that showed low discordance $(<10 \%)$ and low common lead abundances are considered here. Results are displayed in Fig. 8.

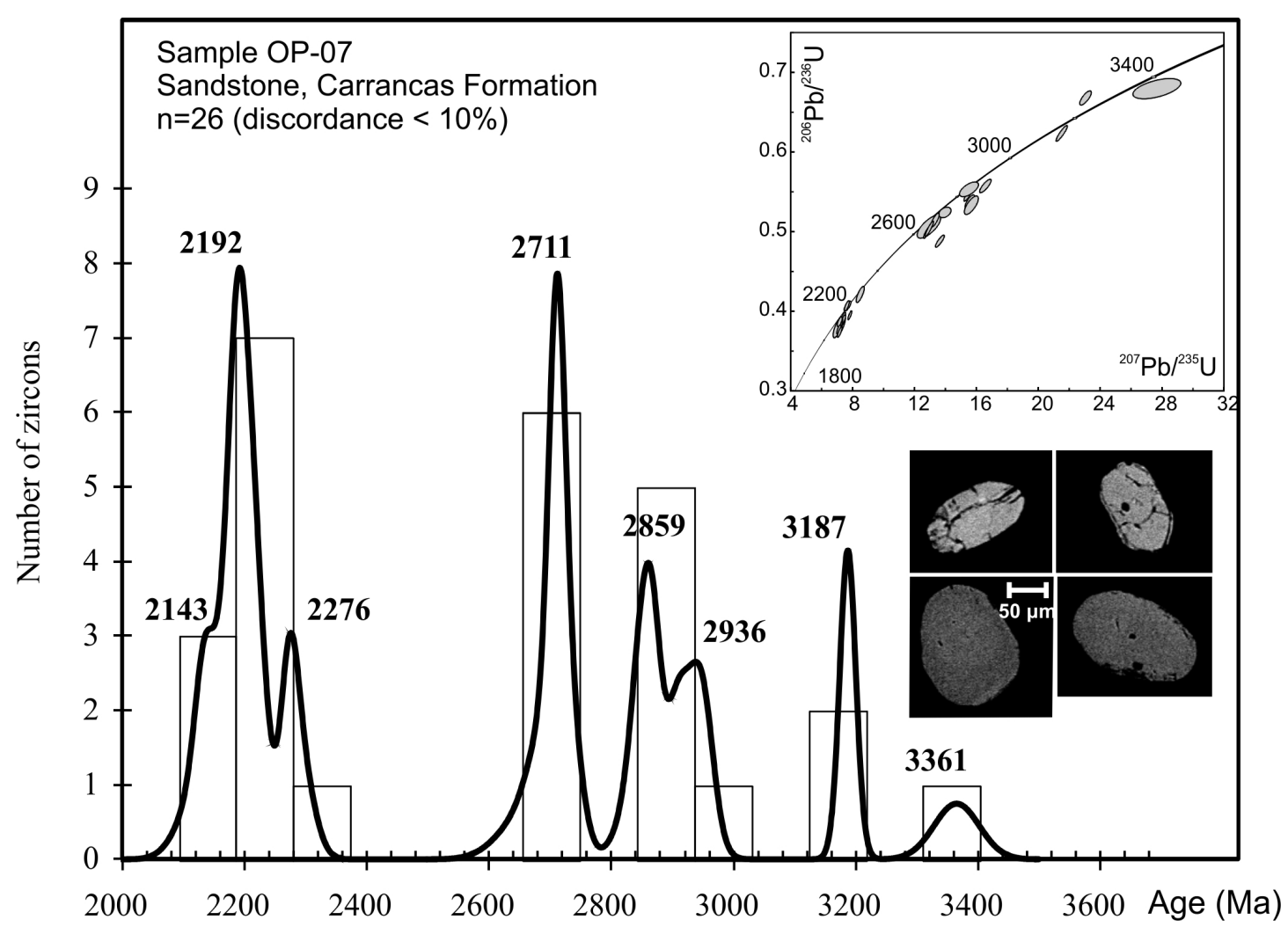

Fig. 8: Frequency histogram, probability curve and concordia diagram of ages obtained from U-Pb (LA-ICP-MS) analyzes on detrital zircon grains extracted from a sandstone sample of the Carrancas

Formation, and scanning electron microscope (SEM) images for some analyzed grains.

The probability density plot encloses 3 main peaks, at 2192, 2711 and 3187 Ma. These data suggest source rocks for the Carrancas Formation within the following ages: 42\% Rhyacian (2204 \pm $11 \mathrm{Ma}) ; 23 \%$ Neoarchean (2712 $\pm 14 \mathrm{Ma})$; and two Mesoarchean peaks of $2887 \pm 15 \mathrm{Ma}(23 \%)$; and $3198 \pm 18 \mathrm{Ma}(12 \%)$.

The bulk of the São Francisco craton is made up of Archean terranes (3.4-2.5 Ga) that coalesced during the Rhyacian orogens (2.2-2.0 Ga; Teixeira et al., 1996; Teixeira et al., 2000; Noce et al., 2000). Thus, the local cratonic basement may have sourced the entire zircon population.

The Archean zircon ages spectra of the Carrancas Formation reflect three main events that affected the southern crust of the São Francisco Craton during the Archean. The ca. 3360 and 3190 Ma peaks relate to the $\mathrm{U}-\mathrm{Pb}$ ages from the crustal generation that may have continued until ca. 2.9- 
$3.0 \mathrm{Ga}$ (Noce et al, 1998). The ca. 2940 and 2860 Ma peaks may represent late stage crustal addition and migmatization events that reworked the protoliths. Finally, the ca. $2710 \mathrm{Ma}$ peak is consistent with reworking and grantic magmatism, which occurred until ca. $2.6 \mathrm{Ga}$, when the cratonic crust stabilized (e.g. Noce et al., 1998; Teixeira et al., 2000). Another potential source of the Archean zircons is reworked metasedimentary rocks of the ca. 2.6-2.5 Ga Rio das Velhas Supergroup, which surround the Carrancas Formation outcrops in the PTA.

The Paleoproterozoic U-Pb zircon ages from the Carrancas Formation define two main peaks of ca. 2280 and $2190 \mathrm{Ma}$, consistent with the pre- to syn-collisional evolution of the

Paleoproterozoic Mineiro belt. This orogenic belt rims the southernmost margin of the São Francisco Craton, from the Quadrilátero Ferrífero westward (Fig. 2) and is composed of gneisses, granitoids, supracrustal sequences, greenstone belts and mafic dykes that were deformed and metamorphosed at 2.1-1.9 Ga (e.g.: Teixeira et al., 2000, 2008).

The U-Pb data include now Mesoproterozoic or Neoproterozoic ages to corroborate the hypothesis of younger source areas based on the Sm-Nd data. In the case of the Carrancas Formation, except for the three northern samples in the PTA with older Nd model ages, all others show $\mathrm{Nd}$ model ages younger than the youngest $\mathrm{U}-\mathrm{Pb}$ age. There are two possible explanations for this geochoronological discrepency One is that the $\mathrm{U}-\mathrm{Pb}$ spectra, like the $\mathrm{Sm}-\mathrm{Nd}$ data, are variable between sites. A second possibility is local confinement of heavy minerals by placer deposition. Sm and $\mathrm{Nd}$ in sediments are concentrated mainly in fine-grained minerals, especially the clay mineral fraction. Clay minerals travel long distances more efficiently than heavy minerals, such as zircon, garnet, monazite, spinel and rutile, which are hydraulically fractionated during transport (Morton and Hallsworth, 1999). The Sm-Nd isotope data suggest contributions from Proterozoic sources, probably located within the Brasília fold belt to the west. As the Carrancas Formation is located on the opposite margin of the basin and was deposited during initiation of the Bambuí basin, the sediment transport systems could have impeded transport of heavy minerals, which were trapped in placer deposits prior to entering the Bambuí basin, whereas younger $\mathrm{Nd}$ and $\mathrm{Sm}$ signals preserved in clays covered large distances.

\subsection{Carbon and oxygen isotopes: correlations and temporal implications}

The reddish dolostone of the Pitangui area and sixteen dolomitic clasts from a conglomerate of the same area were measured for $\delta^{13} \mathrm{C}$ and $\delta^{18} \mathrm{O}$ compositions. A thin interval of laminated limestones which overlap the Carrancas Formation in the BR-040 area was also analyzed for C, O isotopes. All data are presented in Table 4. 
1 Carbon $\left(\delta^{13} \mathrm{C}\right)$ and oxygen $\left(\delta^{18} \mathrm{O}\right)$ isotope compositions of the reddish dolostone range from $2+7.1$ to $+9.6 \%$ and -5.2 to $-6.9 \%$, respectively. The carbonate clasts are all pebble-sized, massive 3 dolomitic clasts that are scattered through a clast-supported conglomerate and yield heavy $\delta^{13} \mathrm{C}$ 4 compositions $(+3.6$ to $+9.4 \%$ ). The thin preserved limestones on top of the Carrancas Formation in 5 the BR-040 area show almost constant values in $\delta^{13} \mathrm{C}(0.68-0.76 \%)$ and $\delta^{18} \mathrm{O}(-8.68$ to $-8.62 \%)$.

6 Table 4: $\delta^{13} \mathrm{C}$ and $\delta^{18} \mathrm{O}$ compositions along with elemental data of carbonate clasts and layers from 7 the Carrancas Formation and Sete Lagoas Formation in studied areas.

\begin{tabular}{|c|c|c|c|c|}
\hline Sample & $\delta^{13} \mathrm{C}_{(\mathrm{VPDB})}$ & $\delta^{18} \mathbf{O}_{\text {(VPDB) }}$ & $\mathrm{Mg} / \mathrm{Ca}$ & $\mathbf{M n} / \mathbf{S r}$ \\
\hline \multicolumn{5}{|c|}{$\begin{array}{l}\text { Reddish dolostone layers } \\
\text { Carrancas Formation - Pitangui area }\end{array}$} \\
\hline OP100-0 & 8.7 & -6.2 & & \\
\hline OP100-0.5 & 8.5 & -6.4 & 0.64 & 16.9 \\
\hline OP100-1 & 8.6 & -6.9 & & \\
\hline OP100-1.5 & 9.2 & -6.6 & 0.65 & 7.6 \\
\hline OP100-2 & 9.3 & -6.5 & & \\
\hline OP100-2.5 & 8.6 & -6.7 & 0.65 & 15.9 \\
\hline OP100-3 & 9.0 & -6.7 & & \\
\hline OP100-3.5 & 9.3 & -6.4 & 0.61 & 9 \\
\hline OP100-4.5 & 9.3 & -6.6 & & \\
\hline OP100-5 & 7.1 & -5.3 & 0.64 & 6.2 \\
\hline OP100-6 & 8.6 & -6.2 & & \\
\hline OP100-7 & 9.1 & -6.6 & 0.68 & 23.1 \\
\hline OP100-8 & 8.2 & -5.4 & & \\
\hline OP100-8.5 & 9.5 & -6.5 & 0.63 & 12.5 \\
\hline OP100-9.5 & 9.4 & -6.5 & & \\
\hline OP100-10 & 9.6 & -5.2 & 0.62 & 10.6 \\
\hline OP100-10.5 & 9.4 & -6.7 & & \\
\hline OP100-11 & 8.3 & -6.3 & 0.71 & 10.5 \\
\hline OP100-11.5 & 8.5 & -6.1 & & \\
\hline OP100-12 & 9.3 & -6.9 & 0.61 & 7.9 \\
\hline OP100-12.5 & 9.5 & -6.6 & & \\
\hline OP100-13.5 & 9.5 & -6.5 & 0.62 & 8.3 \\
\hline
\end{tabular}


Carbonate clasts

Carrancas Formation - Pitangui area

\begin{tabular}{|c|c|c|c|c|}
\hline CAR-C1 & 4.79 & -6.51 & 0.51 & 24.3 \\
\hline CAR-C2 & 7.71 & -8.82 & 0.53 & 12.6 \\
\hline CAR-C3 & 9.23 & -7.19 & 0.52 & 8.8 \\
\hline CAR-C4 & 8.99 & -6.66 & 0.54 & 22.8 \\
\hline CAR-C5 & 9.18 & -6.64 & 0.54 & 10.2 \\
\hline CAR-C6 & 6.73 & -7.46 & 0.52 & 26.3 \\
\hline CAR-C7 & 3.6 & -7.86 & 0.48 & 41.5 \\
\hline CAR-C8 & 9.15 & -7.03 & 0.52 & 16.5 \\
\hline CAR-C9 & 7.53 & -11.45 & 0.5 & 24.5 \\
\hline CAR-C10 & 9.11 & -6.38 & 0.51 & 34 \\
\hline CAR-C11 & 9.38 & -7.31 & 0.53 & 9.4 \\
\hline CAR-C12 & 8.99 & -6.9 & 0.54 & 29.6 \\
\hline CAR-C13 & 8.42 & -7.26 & 0.54 & 7.2 \\
\hline CAR-C14 & 3.88 & -5.93 & 0.52 & 30.3 \\
\hline CAR-C15 & 4.15 & -10.7 & 0.55 & 43.5 \\
\hline CAR-C16 & 8.44 & -8.51 & 0.52 & 14.3 \\
\hline
\end{tabular}

Limestone layers

Sete Lagoas Formation - BR-040 area

\begin{tabular}{llccc} 
SL-0 & 0.68 & -8.68 & 0.01 & 0.7 \\
SL-1 & 0.69 & -8.87 & 0.01 & 0.8 \\
SL-2 & 0.73 & -8.79 & 0.03 & 0.6 \\
SL-2.5 & 0.74 & -8.73 & 0.01 & 0.4 \\
SL-3 & 0.73 & -8.76 & & 0.7 \\
SL-3.5 & 0.77 & -8.6 & & 0.01 \\
SL-4 & 0.76 & -8.62 & & \\
\hline
\end{tabular}

3 The reddish dolostones occur only in the upper part of the Carrancas Formation in the 4 Pitangui area and display strongly positive $\delta^{13} \mathrm{C}$ values, up to $+9.6 \%$ (Fig. 4B). Carbon-isotopic 5 compositions higher than $+5 \%$ in the Bambuí Group are restricted to the middle/upper Sete Lagoas 
1 Formation and throughout the Lagoa do Jacaré Fomation (e.g.: Iyer et al., 1995; Santos et al., 2004;

2 Alvarenga et al., 2007, 2014; Paula-Santos et al., 2015), which are mainly calcitic and dark-gray to black organic-rich limestones, unlike the reddish dolomites. These are the first strongly positive $\delta^{13} \mathrm{C}$

4 data obtained from the lower Bambuí Group. Because these rocks pre-date the Sete Lagoas 5 Formation and are not obviously glaciogenic, they must be pre-Marinoan in age. High $\delta^{13} \mathrm{C}$ 6 carbonates occur both during the Tonian and Cryogenian interglacial interval (Kaufman et al., 1997; 7 Halverson et al., 2005). Although we cannot rule out the possibility that these ${ }^{13} \mathrm{C}$-enriched 8 Carrancas dolostones are earlier Neoproterozoic in age, the most parsimonious interpretation is that they are Cryogenian and correspond to the 'Keele Peak'. This peak in $\delta^{13} \mathrm{C}$ values from +8 to $+10 \%$ is well documented globally (e.g. Kaufman et al., 1997; McKirdy et al., 2001; Halverson et al., 2005; Johnston et al., 2012) and is followed by the Trezona negative carbon isotope anomaly, which shortly precedes the onset of Marinoan glaciation (Halverson et al., 2002).

In the Araçuaí fold belt, to the northeast, the so-called Tijucuçu sequences comprises an $\sim 200$ m-thick mixed siliciclastic-carbonate transgressive sequence tract deposited in a rift to passive margin basin, representing fluvial plain to shallow shelf deposits (Fraga, 2013) (Fig. 1). The Tijucuçu sequence unconformably overlies the Duas Barras and Domingas formations and is itself unconformably overlain by continental and marine glacial diamictites of the Serra do Catuni Formation. All of these units belong to the Cryogenian Macaúbas Group (Pedrosa-Soares et al., 2011; Babinski et al., 2012; Fraga, 2013). Fraga et al. (2014) analyzed C, O isotopes on calcareous layers of the upper $40 \mathrm{~m}$ of the Tijucuçu sequence and obtained almost constant values of $\delta^{13} \mathrm{C}$ around $+10 \%$ with a sharp decrease to $-1.0 \%$ o towards the top. These isotopic values are consistent with the $\delta^{13} \mathrm{C}$ Keele peak followed by the initial decline into the Trezona negative carbon isotope anomaly, implying a pre-Marinoan (ca. $635 \mathrm{Ma}$ ) age for the Tijucuçu sequence and a late Cryogenian pre-glacial record on the eastern margin of the São Francisco craton. correlates with the Jequitaí Formation on the craton (Karfunkel and Hoppe, 1988; Uhlein et al., 1998, 1999; Martins-Neto et al., 2001). Thus, we propose a similar correlation between the preglacial Tijucuçu sequence and Carrancas Formation, in which the continental extension on the southern São Francisco crust may be a minor expression of the rifting at the eastern margin, and suggest that both of these units capture the Keele Peak, and hence represent the Cryogenian interglacial interval.

The histogram in Fig. 9a shows a bimodal distribution for the $\delta^{13} \mathrm{C}$ compositions of the dolomitic clasts in Carrancas Formation conglomerates in the Pitangui area, with a prominent peak at 9.1\%o and four values clustering around 4\%o. This isotopic distribution suggests two different 
carbonate sources. Carbon and oxygen isotope variations are shown in Fig. 9a with a number of samples clustered around $\delta^{13} \mathrm{C}$ and $\delta^{18} \mathrm{O}$ of $+9 \%$ and $-7 \%$, respectively. The $\delta^{13} \mathrm{C}$ and $\delta^{18} \mathrm{O}$ data of the carbonate clasts in the Pitangui area are effectively identical to the reddish dolostone layers and imply an intraformational provenance for clast-supported conglomerate in the Pitangui Area (Fig. 9a and $9 b)$.

Considering that the conglomerate is stratigraphically below the reddish dolostones, another source area with high $\delta^{13} \mathrm{C}$ must be found. This suggests that there were carbonates depositing locally prior to the Keele Peak (dolostone clasts with less positive $\delta^{13} \mathrm{C}$ values), and that the Keele peak may be represented by more than just the high $\delta^{13} \mathrm{C}$ reddish dolostones; i.e. there was tectonism and cannibalization (clast-supported conglomerate deposition) at this time on the southern São Francisco craton and only the end of the Keele Peak is preserved in the Carrancas Formation.

Above the mudstones of the Carrancas Formation in the BR-040 area, a thin interval of laminated limestones is preserved. The $\mathrm{C}$ and $\mathrm{O}$ isotopic compositions are near constant, ranging from 0.68 to $0.76 \%$ for $\delta^{13} \mathrm{C}$ and -8.68 to $-8.62 \%$ for $\delta^{18} \mathrm{O}$. We suggest that this limestone represent the Sete Lagoas Formation and thus display a direct contact between pre- and post-glacial sections. This stratigraphic relation is seen in other outcrops of the Carrancas Formation, as occurrences of the glaciogenic Jequitai Formation are missing in the southern Bambuí basin.

(a)

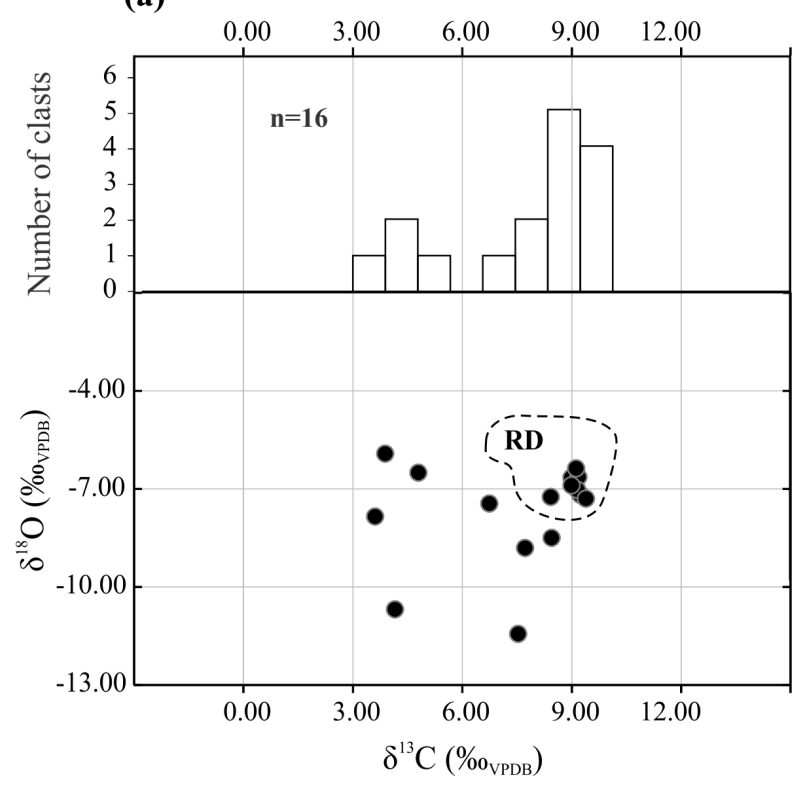

(b) $\quad \delta^{13} \mathrm{C}\left(\% \%_{\text {vPDB }}\right)$

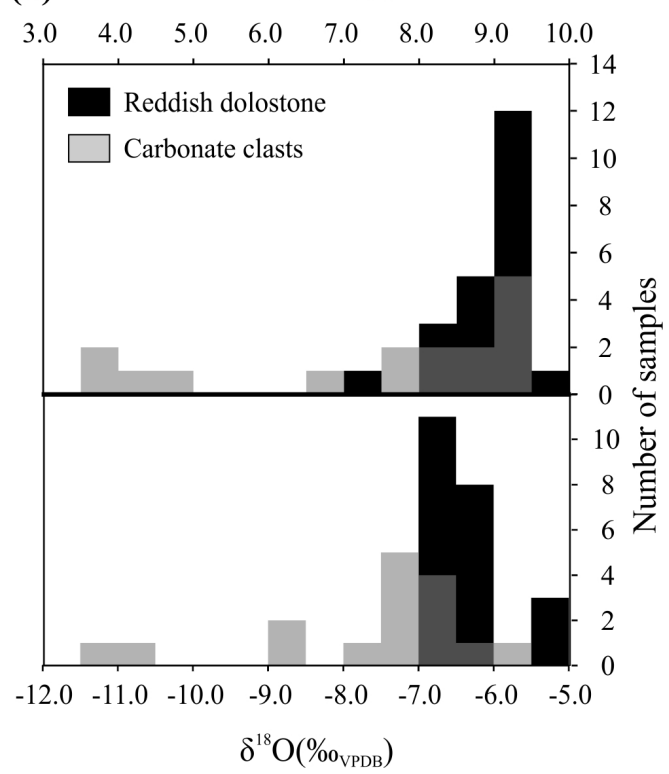

Fig. 9: (a) Histogram and $\delta^{13} \mathrm{C}$ vs $\delta^{18} \mathrm{O}$ crossplot of carbonate clasts from the Pitangui area. RD: isotopic compositional field of the reddish dolostone (b) Histogram of $\delta^{13} \mathrm{C}$ and $\delta^{18} \mathrm{O}$ distribution of carbonate clasts compared to reddish dolostone layers. 
Stratigraphic and isotopic data presented in this paper suggest sedimentation of the Carrancas

2 Formation inside small continental rift basins that opened on the southern São Francisco

3 paleocontinent prior to the onset of the end-Cryogenian (Marinoan) glaciation. Basal conglomerates

4 pass upward and laterally into to turbidites, which are in turn overlain by mudstones, siltstones and

5 black shales deposited during a basin-wide transgression. Reddish dolostones and dolarenites locally

6 occur at the top of the Carrancas Formation. All Facies Associations are recorded in the Pitangui

7 area; however, FA2 and FA4 are missing in the BR-040 and Inhaúma areas. Mudstones and

8 siltstones of FA3 are the main lithocorrelation interval and their first appearance marks a

9 transgressive surface over uplifted basement blocks and intercommunication between previously

10 isolated grabens. Conglomerates, consisting of intrabasinal clasts within the Carrancas Formation

11 (FA1) are interpreted as gravity flow deposits controlled by faulted basin margins. No evidence for

12 glacial influence is present in the Carrancas Formation. Sm-Nd and lithochemical data corroborate

13 deposition within partially connected sub-basins and with a source of poorly-mixed sediments. A

14 well-defined trend of positive $\delta^{13} \mathrm{C}$ values $(+7$ to $+9 \%$ ) for the reddish dolostone beds occur in the

15 upper Carrancas Formation in the Pitangui area, beneath basal Ediacaran cap carbonates of the Sete

16 Lagoas Formation. These anomalous high positive values are identical to those observed during the

17 Cryogenian interglacial Keele peak, and prior to the Trezona negative carbon isotope excursion

18 (Halverson et al., 2005). Another pre-glacial succession in the Araçuaí fold belt to the east - the

19 Tijucuçu sequence - shares similar $\mathrm{C}$ isotopic compositions with the Carrancas Formation (high $\delta^{13} \mathrm{C}$

20 values). We interpret these two units to be correlative, implying a more widespread pre-Marinoan

21 record on the São Francisco craton and surrounding fold belt (Fig. 10). 

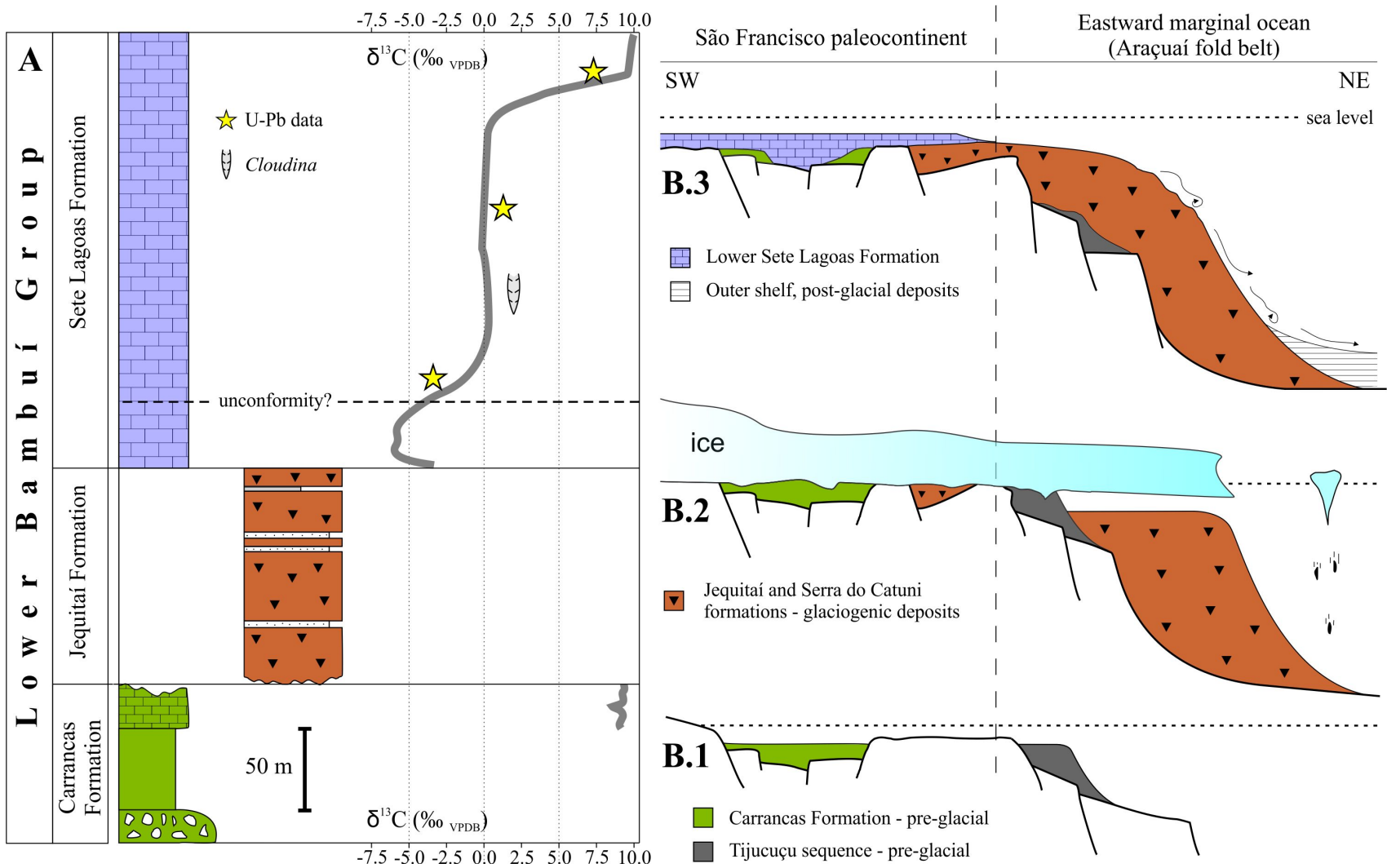

Fig. 10: A) Composite stratigraphic column for the lower Bambuí Group and its $\delta^{13} \mathrm{C}$ isotopic profile, from pre- to post-glacial units. Approximate stratigraphic locations of Cloudina occurrences and $\mathrm{U}-\mathrm{Pb}$ data are based on facies associations and $\delta^{13} \mathrm{C}$ compositions (Warren et al., 2014; PaulaSantos et al., 2015). An unconformity separates the late-Cryogenian to earliest Ediacaran, lower intracratonic sequence, from the late Ediacaran, foreland-basin deposits. B.1, B.2, B.3 show The Cryogenian to basal Ediacaran evolution of the southeast São Francisco crust and its eastern margin, interpreted in terms of three phases: B.1 - Cryogenian interglacial interval. Deposition of the Carrancas Formation inside grabens on the São Francisco crust, and, to the northeast, the Tijucuçu sequence developed over a rift to passive margin basin. B.2 - Onset of the end-Cryogenian glaciation is marked by localized deposition of the Jequitaí Formation in fault-controlled basement lows on the paleocontinent. Its counterpart, the Serra do Catuni Formation, filled a deeper basin to the east with sediment derived predominantly from subglacial meltwater plumes. Basement and preglacial units were intensely eroded by glacial abrasion. B.3 - End of the late Cryogenian (Marinoan) glaciation and deposition of the Sete Lagoas cap carbonate on a shallow shelf. Further east, reworked glacial sediments with sparse calcareous lenses were deposited at the same time.

We propose a new interpretation for the lower Bambuí Group and southern São Francisco paleocontinent that is consistent with the isotopic and stratigraphic data presented in this paper (Fig. 10). The Carrancas Formation was deposited during the Cryogenian interglacial interval in partially connected grabens or half-grabens that were like produced by a minor, short term, rifting event over the southern São Francisco craton (Fig. 4 and Fig. 10-B.1). At the same time on the eastern margin of the craton, the Tijucuçu sequence was deposited within a continental rift that evolved into a passive margin basin. A shallowing upward top and the occurrence of dolostones with high $\delta^{13} \mathrm{C}$ composition 
in the Carrancas Formation highlights a base-level fall that may have heralded the onset of glaciation. At this time, a continental to marine glacial environment occupied much of the São Francisco paleocontinent and its margins (Fig. 10-B.2). The Jequitaí Formation was deposited in an epicontinental sea that flooded the craton, while its counterpart, the Serra do Catuni Formation, filled the passive margin basin at the eastward marginal ocean. Subglacial gravity flows and dropstones from the breakup of the ice shelf are identified throughout the Serra do Catuni and others formations in the Araçuai fold belt (Karfunkel \& Hoppe, 1998; Pedrosa-Soares et al, 2011) (Fig. 10-B.2). Both glaciogenic units share almost identical $\delta^{13} \mathrm{C}\left(0\right.$ to $-7 \%$ ) and $\delta^{18} \mathrm{O}(-7$ to $-15 \%)$ values for their carbonate clasts, including a few clasts with positive $\delta^{13} \mathrm{C}$ as high as $+7 \%$ (Caxito et al., 2012 and references there in). Thus, erosion of a pre-glacial carbonate platform with mainly negative $\delta^{13} \mathrm{C}$ values was suggested by Caxito et al. (2012). The Carrancas Formation and the Tijucuçu sequence are likely candidates for the source of ${ }^{13} \mathrm{C}$-enriched carbonate clasts within the glacial diamictites, while the older Domingas Formation and the upper Tijucuçu sequence carbonates may be the source for carbonate clasts with negative $\delta^{13} \mathrm{C}$ composition (Santos et al. 2004; Caxito et al., 2012). Subglacial erosion and post-glacial rebound may also have reinforced the patchy preservation pattern of the Carrancas Formation. Cap carbonate of the lower Sete Lagoas Formation deposited immediately in the aftermath of the end-Cryogenian glaciation filled an irregular relief, likely accentuated by glacial erosion and glacio-isostatic rebound along the shoreline (Fig. 10-B.3) (Vieira et al., 2007a, 2015). A foreslope equivalent of the post-glacial carbonate platform developed over an outer shelf environment to the east, represented by reworked glacial sediments and intercalated carbonate lenses (Fig. 10-B.3).

The Jequitaí Formation does not occur in the southern Bambui basin, probably due to the presence of the Sete Lagoas paleo-high, which may have hindered the preservation of glaciogenic sediments. The thickest and best exposed occurrences of the Jequitaí Formation are located away from these paleo-highs (e.g.: Cuckov et al., 2005; Uhlein et al., 2011b). Although debate persists over the depositional age of the Jequitaí Formation and the entire Bambuí Group, stratigraphic and isotopic data from the lowermost Bambuí are consistent with a late-Cryogenian to earliest Ediacaran age. Indeed, the Bambui Group appears to span the entirely end-Cryogenian (Marinoan) glaciation event and the post-glacial transgression. To the extent that the middle to upper Bambuí Group is late Ediacaran, as implied by fossil and zircon data, this suggests an unconformity in the middle of the Sete Lagoas Formation carbonates, separating a lower end-Cryogenian to earliest Ediacaran basin, from a middle to late Ediacaran basin (Fig. 10A). 
This paper is part of continuous work on the Bambuí Group headed by the Neoproterozoic research group of the Universidade Federal de Minas Gerais, Brazil. GJU was supported by research grant from $\mathrm{CNPq}$ and by the ELAP (Emerging Leaders in the Americas Program) of the Canadian

Bureau for International Education/Foreign Affairs and International Trade Canada, during his stay at the GEOTOP Research Center, Montréal, Canada. AU is supported by CNPq (447449/2014-1) and FAPEMIG grants (APQ-01711-14). GPH's involvement in this project was supported by an NSERC Discovery grant. FAC is supported by FAPEMIG grants APQ-00914-14 and PPM-00539-15. GMC was supported by a NSERC Vanier Fellowship.

\section{REFERENCES}

ALKMIM, F.F. (2004) O que faz de um cráton um cráton? O Cráton do São Francisco e as revelacões almeidianas ao delimitá-lo. In: Geologia do Continente Sul-Americano: evolucão da obra de Fernando Flávio Marques de Almeida (Ed. by V. Mantesso-Neto, A. Bartorelli, C. D. R. Carneiro \& B. B. Brito-Neves), pp. 17-35. Beca, São Paulo.

ALKMIM, F.F. \& MARSHAK S. (1998). Transamazonian Orogeny in the Southern São Francisco Craton Region, Minas Gerais, Brazil: evidence for Paleoproterozoic collision and collapse in the Quadrilátero Ferrífero. Precambrian Research, 90, 29-58

ALKMIM, F.F. \& MARTINS-NETO, M.A. (2001) A bacia intracratônica do São Francisco: arcabouço estrutural e cenários evolutivos. In: A Bacia do São Francisco. Geologia e recursos naturais (Ed. by C. P. Pinto \& M. A. Martins-Neto), pp. 9-30. SBG, Belo Horizonte.

ALLEN, P.A. \& HOFFMAN, P.F. (2005) Extreme winds and waves in the aftermath of a Neoproterozoic glaciation. Nature, 433, 123-127.

ALMEIDA, F.F.M. (1977) O Cráton do São Francisco. Revista Brasileira de Geociências, 7, 349364.

ALVARENGA, C.J.S., GIUSTINA, M.E.S.D, SILVA, N.G.C., SANTOS, R.V., GIOIA, S.M.C.L., GUIMARÃES E.M., DARDENNE, M.A., SIAL, A.N., FERREIRA V.P. (2007) Variações dos isótopos de $\mathrm{C}$ e $\mathrm{Sr}$ em carbonatos pré e pós-glaciação Jequitaí (Esturtiano) na região de Bezerra-Formosa, Goiás. Revista Brasileira de Geociências, 37(4), 147-155.

ALVARENGA, C.J.S., SANTOS, R.V., VIEIRA, L.C., LIMA, B.A.F., MANCINI L.H. (2014) Meso-Neoproterozoic isotope stratigraphy on carbonates platforms in the Brasilia Belt of Brazil. Precambrian Research, 251, 164-180.

BABINSKI, M., PEDROSA-SOARES, A.C., TRINDADE, R.I.F., MARTINS, M., NOCE, C.M., LIU, D. (2012) Neoproterozoic glacial deposits from the Araçuaí orogen, Brazil: age, provenance and correlations with the São Francisco craton and West Congo belt. Gondwana Research, 21, 451-465.

BABINSKI, M., VIEIRA, L.C. \& TRINDADE, R.I.F. (2007) Direct dating of the Sete Lagoas cap carbonate (Bambuí Group, Brazil) and implications for the Neoproterozoic glacial events. Terra Nova, 19, 401-406.

BOYNTON, W.V. (1984) Cosmochemistry of the rare earth elements: meteorite studies. In: Rare Earth Element Geochemistry (Ed. by P. Henderson), pp. 63-114. Elsevier, Amsterdam.

BÜHN, B., PIMENTEL, M.M., MATTEINI, M. \& DANTAS, E.L. (2009) High spatial resolution analysis of $\mathrm{Pb}$ and $\mathrm{U}$ isotopes for geochronology by laser ablation multi-collector inductively coupled plasma mass spectrometry (LA-MC-IC-MS). Anais da Academia Brasileira de Ciências, 81, 1-16. 
CAXITO, F.A., HALVERSON, G.P., UHLEIN, A., STEVENSON, R., DIAS, T.G. \& UHLEIN, G.J. (2012) Marinoan glaciation in east central Brazil. Precambrian Research, 200-203, 3858.

CHAVES, A.O., NEVES J.M.C. (2005) Radiometric ages, aeromagnetic expression, and general geology of mafic dykes from southeastern Brazil and implications for African-South American correlations. Journal of South American Earth Sciences, 19, 387-397.

CONDIE, K.C. (1993) Chemical composition and evolution of the upper continental crust: contrasting results from surface samples and shales. Chemical Geology 104, 1-37.

CUKROV, N., ALVARENGA, C.J.S., UHLEIN, A. (2005) Litofácies da glaciação neoproterozoica nas porções sul do cráton do São Francisco: Exemplos de Jequitaí (MG) e Cristalina (GO). Revista Brasileira de Geociências, 35(1), 69-76.

DARDENNE, M.A. (1978) Síntese sobre a estratigrafia do Grupo Bambuí no Brasil Central. 30 Congresso Brasileiro de Geologia. 2, 597-610.

DAVID, M.E.V. (2011) Estudo termocronológico e evolução metalogenética da mineralização aurífera do Depósito Turmalina - MG. PhD Thesis, USP, Instituto de Geociências, 142p.

EVANS, D.A.D. (2000) Stratigraphic, geochronological, and paleomagnetic constraints upon the Neoproterozoic climatic paradox. American Journal of Science, 300, 347-433.

EYLES, N. \& JANUSZCZAK, N. (2004) 'Zipper-rift': a tectonic model for Neoproterozoic glaciations during the breakup of Rodinia after 750 Ma. Earth-Science Reviews, 65, 1-73.

FRAGA, L.M.S. (2013) Análise estratigráfica do Grupo Macaúbas no domínio meridional da Serra do Espinhaço, Minas Gerais. PhD Thesis, UFMG, IGC, 189p.

FRAGA, L.M.S., NEVES, S.C., UHLEIN, A., SIAL, A.N., PIMENTEL, M.M., HORN A.H. (2014) C-, Sr-isotope stratigraphy of carbonate rocks from the Southern Espinhaço Ridge, Minas Gerais, southeastern Brazil. Anais da Academia Brasileira de Ciências, 86, 633-648.

FONT, E., NÉDÉLEC, A., TRINDADE, R.I.F. \& MOREAU, C. (2010) Fast or slow melting of the Marinoan snowball Earth? The cap dolostone record. Palaeogeography, Palaeoclimatology, Palaeoecology, 295, 215-225.

GIRTY, G.H., RIDGE，D.L., KNAACK, C., JOHNSON，D. \& AL-RIYAMI，R.K. (1996) Provenance and depositional setting of Paleozoic chert and argillite, Sierra Nevada, California. Journal of Sedimentary Research, 66, 107-118.

GOLDSTEIN, S.L., ONIONS, R.K., HAMILTON, P.J. (1984) A Sm-Nd isotopic study of atmospheric dusts and particulates from major river systems. Earth and Planetary Science Letters, 70, 221-236.

GONÇALVES, L., ALKMIM, F.F., PEDROSA-SOARES, A.C., DUSSIN, I.A., VALERIANO, C.M., LANA, C., TEDESCHI, M. (2015) Granites of the intracontinental termination of a magmatic arc: an example from the Ediacaran Araçuaí orogen, southeastern Brazil. Gondwana Research, http://dx.doi.org/10.1016/j.gr.2015.07.015

GUIRRA, A.P.M., REIS, H.L.S., SUSS, J., ALKMIM, F.F. (2014) A porção basal do Grupo Bambuí na região de Pompéu (MG): Levantamento estratigráfico preliminar baseado em dados de poço. In: Congresso Brasileiro de Geologia, 47, Anais, vol.1

HALVERSON, G.P., HOFFMAN, P.F., SCHRAG, D.P., KAUFMAN, A.J. (2002) A major perturbation of the carbon cycle before the Ghaub glaciation (Neoproterozoic) in Namibia: Prelude to snowball Earth? Geochemistry, Geophysics, Geosystems, 3, 16p.

HALVERSON, G.P., HOFFMAN, P.F., SCHRAG, D.P., MALOOF, A.C., RICE, A.H.N. (2005). Toward a Neoproterozoic composite carbon-isotope record. GSA Bulletin, 117, 1181-1207.

HALVERSON, G.P., MALOOF, A.C. \& HOFFMAN, P.F. (2004) The Marinoan glaciation (Neoproterozoic) in northeast Svalbard. Basin Research, 16, 297-324.

HOFFMAN, P.F. (2011) Strange bedfellows: glacial diamictite and cap carbonate from the Marinoan $(635 \mathrm{Ma})$ glaciation in Namibia. Sedimentology, 58, 57-119. 
HOFFMAN, P.F. \& HALVERSON, G.P. (2008) Otavi Group of the western Northern Platform, the Eastern Kaoko Zone and the western Northern Margin Zone. In: The Geology of Namibia (Ed. by R. M. Miller), pp. 69-136. Geological Survey of Namibia, Windhoek.

HOFFMAN, P.F., HALVERSON, G.P., DOMACK, E.W., HUSSON, J.M., HIGGINS, J.A. \& SCHRAG, D.P. (2007) Are basal Ediacaran (635 Ma) post-glacial "cap dolostones" diachronous? Earth and Planetary Science Letters, 258, 114-131.

HOFFMAN, P.F. \& LI, Z.-X. (2009) A palaeogeographic context for Neoproterozoic glaciation. Palaeogeography, Palaeoclimatology, Palaeoecology, 277, 158-172.

HOFFMAN., P.F. \& SCHRAG, D.P. (2002) The snowball Earth hypothesis: testing the limits of global change. Terra Nova, 14, 129-155.

ISOTTA, C.A.L., ROCHA-CAMPOS, A.C., YOSHIDA, R. (1969) Striated pavement of the Upper Precambrian glaciation in Brazil. Nature, 222, 466-468.

IYER, S.S., BABINSKI M., KROUSE H.R., CHEMALE Jr., F. (1995) Highly 13C-enriched carbonate and organic matter in the Neoproterozoic sediments of the Bambuí Group, Brazil. Precambrian Research, 73, 271-282.

JAMES, N.P., NARBONNE, G.M., KYSER, T.K. (2001). Late Neoproterozoic cap carbonates: Mackenzie Mountains, northwestern Canada: Precipitation and global glacial meltdown. Canadian Journal of Earth Sciences, 38, 1229-1262.

JOHNSTON, D.T., MACDONALD, F.A., GILL, B.C., HOFFMAN, P.F., SCHRAG, D.P. (2012) Uncovering the Neoproterozoic carbon cycle, Nature, 483, 320-323.

KARFUNKEL, J. \& HOPPE, A. (1988) Late Precambrian glaciation in central-eastern Brazil: synthesis and model. Palaeogeography Palaeoclimatology Palaeoecology, 65, 1-21.

KAUFMAN, A.J., KNOLL, A.H., NARBONNE, G.M. (1997) Isotopes, ice ages, and terminal Proterozoic earth history: Proceedings of the National Academy of Sciences of the United States of America, 94, 6600-6605.

KENNEDY, M.J. \& CHRISTIE-BLICK, N. (2011) A condensation origin for Neoproterozoic cap carbonates. Geology, 39, 319-322.

LAMB, M.P., FISCHER, W.W., RAUB, T.D., PERRON, J.T., MYROW, P.M. (2012) Origin of giant wave ripples in snowball Earth cap carbonate. Geology, 40, 827-830.

LUDWIG, K.R. (2008) User's manual for Isoplot 3.6. A geochronological toolkit for Microsoft Excel. Special Publication, No. 4, Berkeley Geochronologic Center. Berkeley, USA.

MARTINS, M. \& LEMOS, V.B. (2007) Análise estratigráfica das seqüências neoproterozóicas da Bacia do São Francisco. Revista Brasileira de Geociências, 37, 156-167.

MARTINS-FERREIRA, M,A,C., CAMPOS, J.E.G., ALVARENGA, C.J.S. (2013). A Formação Jequitaí na região de Vila Boa, GO: exemplo de sedimentação por geleiras terminais no Neoproterozóico. Brazilian Journal of Geology, 43(2), 373-384.

MARTINS-NETO, M.A., PEDROSA-SOARES, A.C., LIMA S.A.A. (2001) Tectono-sedimentary evolution of sedimentary basins from late Paleoproterozoic to late Neoproterozoic in the São Francisco Craton and Araçuaí fold belt, eastern Brazil. Sedimentary Geology, 141-142, 343370.

MCKIRDY, D.M., BURGESS, J.M., LEMON, N.M., YU, X., COOPER, A.M., GOSTIN, V.A., JENKINS, R.J.F., BOTH, R.A. (2001) A chemostratigraphic overview of the late Cryogenian interglacial sequence in the Adelaide Fold-Thrust Belt, South Australia. Precambrian Research, 106, 149-186.

MCLENNAN, S.M. (1989) Rare earth elements in sedimentary rocks: influence of provenance and sedimentary processes. . In: Geochemistry and Mineralogy of the Rare Earth Elements (Ed. by B. Lipin \& G. McKay), pp. 169-200. Mineralogical Society of America.

MCLENNAN, S.M. \& HEMMING S. (1992) Samarium/neodymium elemental and isotopic systematics in sedimentary rocks. Geochimica e Cosmochimica Acta, 56, 887-898. 
MORTON, A.C. \& HALLSWORTH, C.R. (1999) Processes controlling the composition of heavy mineral assemblages in sandstones. Sedimentary Geology, 124, 3-29.

NOCE, C.M., MACHADO, N. \& TEIXEIRA, W. (1998) U-Pb geochronology of gneisses and granitoids in the Quadrilátero Ferrífero (southern São Francisco craton): age constraints for Archean and Paleoproterozoic magmatism and metamorphism. Revista Brasileira de Geociências, 28, 95-102.

NOCE, C.M., TEIXEIRA, W., QUÉMÉNEUR, J.J.G., MARTINS, V.T.S. \& BOLZACHINI, E. (2000) Isotopic signatures of Paleoproterozoic granitoids from the southern São Francisco Craton and implications for the evolution of the Transamazonian Orogeny. Journal of South American Earth Sciences, 13, 225-239.

PAULA-SANTOS, G.M., BABINSKI, M., KUCHENBECKER, M., CAETANO-FILHO, S., TRINDADE, R.I.F. \& PEDROSA-SOARES, A.C. (2015) New evidence of an Ediacaran age for the Bambuí Group in southern São Francisco craton (eastern Brazil) from zircon U-Pb data and isotope chemostratigraphy. Gondwana Research, 18, 1-19.

PEDROSA-SOARES, A.C., BABINSKI, M., NOCE, C.M., MARTINS, M.S., QUEIROGA, G. \& VILELA, F. (2011) The Neoproterozoic Macaúbas Group (Araçuaí orogen, SE Brazil) with emphasis on the diamictite formations. In: The Geological Record of Neoproterozoic Glaciations (Ed. by E. Arnaud, G. P. Halverson \& G. Shields), Memoir 36, pp. 523-534. Geological Society of London, London.

PEDROSA-SOARES, A.C., NOCE, C.M., WIEDEMANN, C.M., PINTO, C.P. (2001) The AraçuaíWest Congo orogen in Brazil: An overview of a confined orogen formed during Gondwanland assembly. Precambrian Research, 110, 307-323.

PIMENTEL, M.M., DARDENNE, M.A., FUCK, R.A., VIANA, M.G., JUNGES, S.L., FISCHEL, D.P., SEER, H.J. \& DANTAS, E.L. (2001) Nd isotopes and the provenance of detrital sediments of the Neoproterozoic Brasília Belt, central Brazil. Journal of South American Earth Sciences, 14, 571-585.

PIMENTEL, M.M., FUCK, R.A. \& GIOIA, S.M.C.L. (2000) The Neoproterozoic Goiás magmatic arc, central Brazil: A review and new Sm-Nd isotopic data. Revista Brasileira de Geociências, 30, 35-39.

PIMENTEL, M.M., RODRIGUES, J.B., DELLAGIUSTINA, M.E.S., JUNGES, S., MATTEINI, M. \& ARMSTRONG, R. (2011) The tectonic evolution of the Neoproterozoic Brasília Belt, central Brazil, based on SHRIMP and LA-ICPMS U-Pb sedimentary provenance data: A review. Journal of South American Earth Sciences, 31, 345-357.

PIN, C. \& ZALDUEGUI, J.F.S. (1997) Sequential separation of light rare-earth elements, thorium, and uranium by miniaturized extraction chromatography: application to isotopic analyses of silicate rocks. Analytica Chimica Acta, 339, 79-89.

REIS, H.L.S., ALKMIM, F.F. (2015) Anatomy of a basin-controlled foreland fold-thrust belt curve: the Três Marias salient, São Francisco basin, Brazil. Marine and Petroleum Geology, http://dx.doi.org/10.1016/j.marpetgeo.2015.07.013

RIBEIRO, J.H., TULLER, M.P., PINHO, J.M.M., SIGNORELLI, N., FÉBOLI, W.L. (2008) A fácies diamictito da Formação Carrancas, Grupo Bambuí, na região sudoeste da bacia do São Francisco, Minas Gerais. In: Congresso Brasileiro de Geologia, 44, Anais, p.913.

ROCHA-CAMPOS, A.C., YOUNG, G.M., SANTOS, P.R. (1996) Re-examination of a striated pavement near Jequitaí, MG: implications for proterozoic stratigraphy and glacial geology. Anais da Academia Brasileira de Ciências, 68(4), 593.

RODRIGUES, J.B. (2008) Proveniência de sedimentos dos grupos Canastra, Ibiá, Vazante e Bambuí - um estudo de zircões detríticos e idades modelo Sm-Nd. PhD Thesis, UnB, IG, 128p.

ROMANO, A.W. (2007) Nota explicativa da Folha Pará de Minas (SE.23-Z-C-IV) 1:100.000. Convênio CPRM-UFMG, 65p. 
ROMANO, A.W. \& KNAUER, L.G. (2003) Evidências da glaciação neoproterozoica na base do Grupo Bambuí - região de Onça do Pitangui - Minas Gerais. In: Simpósio de Gelogia de Minas Gerais, 12, Anais, v. 1

SANTOS, R.V., ALVARENGA, C.J.S., BABINSKI, M., RAMOS, M.L.S., CUKROV, N., FONSECA, M.A., SIAL, A.N., DARDENNE, M.A., NOCE, C.M. (2004) Carbon isotopes of Mesoproterozoic-Neoproterozoic sequences from Southern São Francisco craton and Araçuaí Belt, Brazil: Paleographic implications. Journal of South American Earth Sciences, 18, 27-39.

SANTOS, T.R. (2012). Quimioestratigrafia das rochas carbonáticas da Formação Sete Lagoas: Grupo Bambuí - Arcos, MG. MSc. Dissertation, UFPR, 132p.

SGARBI, G.N.C., TULLER, M.P.; RIBEIRO, J.H., MARTINS-NETO M.A. (2003) The Carrancas Facies and the Sete Lagoas Formation: the record of the Neoproterozoic Snowball Earth glaciation in the Bambuí Group, São Francisco Basin. In: Simpósio de Geologia de Minas Gerais, 12, Anais, p.30.

SHIELDS, G.A. (2005) Neoproterozoic cap carbonates: a critical appraisal of existing models and the plumeworld hypothesis. Terra Nova, 17, 299-310.

SIAL, A.N., DARDENNE, M.A., MISI, A., PEDREIRA, A.J., GAUCHER, C., FERREIRA, V.P., SILVA-FILHO, M.A., UHLEIN, A., PEDROSA-SOARES, A.C., SANTOS, R.V., EGYDIOSILVA, M., BABINSKI, M., ALVARENGA, C.J.S., FAIRCHILD, T.R. \& PIMENTEL, M.M. (2009) The São Francisco Palaeocontinent. In: Neoproterozoic-Cambrian Tectonics, Global Change and Evolution: a focus on southwestern Gondwana (Ed. by C. Gaucher, A. N. Sial, G. P. Halverson \& H. E. Frimmel), Developments in Precambrian Geology, 16, pp. 3169. Elsevier.

TAYLOR, S.R. \& MCLENNAN, S.M. (1985) The continental crust. Its composition and evolution. Blackwell, Oxford.

TEIXEIRA, W., ÁVILA, C.A. \& NUNES, L.C. (2008) Nd-Sr isotopic geochemistry and U-Pb geochronology of Fé granitic gneiss and Lajedo granodiorite: implications for Paleoproterozoic evolution of the Mineiro belt, southern São Francisco Craton. Geologia USP Série Científica, 8, 53-73.

TEIXEIRA, W., CARNEIRO, M.A., NOCE, C.M., MACHADO, N., SATO, K. \& TAYLOR, P.T. (1996) $\mathrm{Pb}, \mathrm{Sr}$ and $\mathrm{Nd}$ isotope constraints on the Archaean evolution of gneissic-granitoid complexes in the southern São Francisco Craton, Brazil. Precambrian Research, 78, 151-164.

TEIXEIRA, W., SABATE, P., BARBOSA, J., NOCE, C.M. \& CARNEIRO, M.A. (2000) Archean and Paleoproterozoic Tectonic Evolution of the São Francisco Craton, Brazil. In: Tectonic Evolution of South America (Ed. by U. G. Cordani, E. J. Milani, A. Thomaz-Filho \& D. A. Campos), pp. 101-137. 31st IGC, Rio de Janeiro.

TRINDADE, R.I.F. \& MACOUIN, M. (2007) Palaeolatitude of glacial deposits and palaeogeography of Neoproterozoic ice ages. Comptes Rendus Geoscience, 339, 200-211.

TULlER, M.P., RIBEIRO, J.H., SIGNORELLI, M., FEBOLI, W.L. \& PINHO, J.M.M. (2008) Proposta de uma nova seção-tipo da Formação Carrancas, Grupo Bambuí, na região de Inhaúma, Minas Gerais. $44^{\circ}$ Congresso Brasileiro de Geologia, 929.

UHLEIN, A., ALVARENGA, C.J.S., DARDENNE, M.A. \& TROMPETTE, R.R. (2011b) The glaciogenic Jequitaí Formation, southeastern Brazil. In: The Geological Record of Neoproterozoic Glaciations (Ed. by E. Arnaud, G. P. Halverson \& G. Shields-Zhou), Memoir 36, pp. 51-66. Geological Society of London, London.

UHLEIN, A., BAPTISTA, M.C., SEER, H.J., CAXITO, F.A., UHLEIN, G.J. \& DARDENNE, M.A. (2011a) A Formação Lagoa Formosa, Grupo Bambuí (MG): sistema deposicional de leque submarino em bacia de ante-país. Geonomos, 19, 163-172.

UHLEIN, A., TROMPETTE, R.R., ALVARENGA C.J.S. (1999) Neoproterozoic glacial and gravitational sedimentation on a continental rifted margin: The Jequitaí-Macaúbas sequence (Minas Gerais, Brazil). Journal of South American Earth Sciences, 12, 435-451. 
UHLEIN, A., TROMPETTE, R.R., EGYDIO-SILVA, M. (1998) Proterozoic rifting and closure, SE border of the São Francisco Craton, Brazil. Journal of South American Earth Sciences, 11, 191-203.

Uhlein, G.J., CARVAlHO, J.F.M.G., UHlein, A., CAXITO, F.A., HALVERSON, G.P. \& SIAL, A. (2013) Estratigrafia e Sedimentologia da Formação Carrancas, Grupo Bambuí, nas regiões de Belo Horizonte e Pitangui, MG. Geonomos, 20, 18.

VALERIANO, C.M., TEIXEIRA, W., HEILBRON, M. \& SIMÕES, L.S.A. (2000) Southern Brasília Belt (SE Brazil): Tectonic discontinuities, K-Ar data and evolution during the Neoproterozoic Brasiliano Orogeny. Revista Brasileira de Geociências, 30, 195-199.

VIEIRA, L.C., ALMEIDA, R.P., TRINDADE, R.I.F., NOGUEIRA, A.C.R. \& JANIKIAN, L. (2007a) A Formação Sete Lagoas em sua área tipo: fácies, estratigrafia e sistemas deposicionais. Revista Brasileira de Geociências, 37, 1-14.

VIEIRA, L.C., TRINDADE R.I.F., NOGUEIRA A.C.R., ADER M. (2007b) Identification of a Sturtian cap carbonate in the Neoproterozoic Sete Lagoas carbonate platform, Bambuí Group, Brazil. Comptes Rendus Geoscience, 339, 240-258.

VIEIRA, L.C., NÉDÉLEC A., FABRE, S., TRINDADE, R.I.F., ALMEIDA, R.P. (2015) Aragonite crystal fans in Neoproterozoic cap carbonates: a case study from Brazil and implications for the post-snowball earth coastal environment. Journal of Sedimentary Research, 85, 285-300.

WARREN, L.V., QUAGLIO, F., RICCOMINI, C., SIMOES, M.G., POIRE, D.G., STRIKIS, N.M., ANELLI, L.E. \& STRIKIS, P.C. (2014) The puzzle assembled: Ediacaran guide fossil Cloudina reveals an old proto-Gondwana seaway. Geology, 42, 391-394.

ZALÁN, P.V. \& ROMEIRO-SILVA, P.C. (2007) Proposta de mudança significativa na coluna estratigráfica da Bacia do São Francisco. In: Simpósio de Geologia do Sudeste, 10, Diamantina, SBG-MG, Programação e Livro de Resumos, p. 96. 